\title{
ARTICLE
}

\section{Chitosan confinement enhances hydrogen photogeneration from a mimic of the diiron subsite of [FeFe]-hydrogenase}

\author{
Jing-Xin Jian ${ }^{1, \star}$, Qiang Liu' ${ }^{1,2, \star}$, Zhi-Jun $\mathrm{Li}^{1}$, Feng Wang ${ }^{1}$, Xu-Bing $\mathrm{Li}^{1}$, Cheng-Bo Li ${ }^{1}$, Bin Liu ${ }^{1}$, \\ Qing-Yuan Meng ${ }^{1}$, Bin Chen ${ }^{1}$, Ke Feng $^{1}$, Chen-Ho Tung ${ }^{1} \&$ Li-Zhu Wu ${ }^{1}$
}

Nature has created [FeFe]-hydrogenase enzyme as a hydrogen-forming catalyst with a high turnover rate. However, it does not meet the demands of economically usable catalytic agents because of its limited stability and the cost of its production and purification. Synthetic chemistry has allowed the preparation of remarkably close mimics of [FeFe]-hydrogenase but so far failed to reproduce its catalytic activity. Most models of the active site represent mimics of the inorganic cofactor only, and the enzyme-like reaction that proceeds within restricted environments is less well understood. Here we report that chitosan, a natural polysaccharide, improves the efficiency and durability of a typical mimic of the diiron subsite of [FeFe]-hydrogenase for photocatalytic hydrogen evolution. The turnover number of the self-assembling system increases $\sim 4,000$-fold compared with the same system in the absence of chitosan. Such significant improvements to the activity and stability of artificial [FeFe]-hydrogenase-like systems have, to our knowledge, not been reported to date.

\footnotetext{
${ }^{1}$ Key Laboratory of Photochemical Conversion and Optoelectronic Materials, Technical Institute of Physics and Chemistry \& University of Chinese Academy of Sciences, the Chinese Academy of Sciences, Beijing 100190, China. ${ }^{2}$ State Key Laboratory of Applied Organic Chemistry, Lanzhou University, Lanzhou 730000, China. * These authors contributed equally to this work. Correspondence and requests for materials should be addressed to L.-Z.W, (email: Izwu@mail.ipc.ac.cn).
} 
E nzymes may bind substrates through multiple interactions in elaborate pockets to direct a specific reaction pathway under mild conditions ${ }^{1-4}$. [FeFe]-hydrogenase ([FeFe]$\mathrm{H}_{2}$ ase $)^{5,6}$, a natural enzyme for hydrogen $\left(\mathrm{H}_{2}\right)$ evolution, is deeply embedded within the protein matrix to enable the reversible reduction of protons to $\mathrm{H}_{2}$ with low overpotential and high turnover frequencies (TOF 6,000-9,000 s $\mathrm{s}^{-1}$ per catalytic site). The high-resolution $\mathrm{X}$-ray crystallographic structures establish that $[\mathrm{FeFe}]-\mathrm{H}_{2}$ ase, isolated from Desulfovibrio desulfuricans ${ }^{5}$ and Clostridium pasteurianum ${ }^{6}$, features a butterfly $\left[\mathrm{Fe}_{2} \mathrm{~S}_{2}\right]$ subunit coordinated by a cysteinelinked $\left[\mathrm{Fe}_{4} \mathrm{~S}_{4}\right]$ cluster, carbon monoxide and cyanide ligands, and by a dithiolate bridging the two iron centres. The diiron $\left[\mathrm{Fe}_{2} \mathrm{~S}_{2}\right]$ subunit serves as the catalytic centre for proton reduction, and the $\left[\mathrm{Fe}_{4} \mathrm{~S}_{4}\right]$ cluster mediates transfer electron to and from the active site of the $\mathrm{H}$-cluster. The astonishing rates of $\mathrm{H}_{2}$ production from the non-precious diiron catalysts via a group of enzymes under mild conditions can exceed those of platinum. However, the large-scale isolation of the enzyme from natural systems is rather difficult, hence the development of artificial $[\mathrm{FeFe}]-\mathrm{H}_{2}$ ase analogues capable of reproducing the enzymic activity has spurred considerable interest in both the scientific and industrial communities ${ }^{7-25}$. Over the past decade, a variety of mimics of the diiron subsite of $[\mathrm{FeFe}]-\mathrm{H}_{2}$ ase have been shown to function as catalysts for chemical reduction of protons ${ }^{26-33}$. It has been clear that electron transfer, either electrochemical or photochemical, to a mimic of the active site of $[\mathrm{FeFe}]-\mathrm{H}_{2}$ ase is a prerequisite for $\mathrm{H}_{2}$ evolution ${ }^{10-14,22}$. From a photochemical point of view, the electron transfer is triggered by the absorption of a photon by a photosensitizer ${ }^{13-25}$. Since the first attempt by Sun and Åkermark ${ }^{34}$ to construct an artificial photocatalytic system for $\mathrm{H}_{2}$ evolution in 2003, a large number of synthetic model complexes have been pursued to mimic the structure and functionality of the diiron subunit of the natural $[\mathrm{FeFe}]-\mathrm{H}_{2}$ ase $\mathrm{H}$-cluster ${ }^{35-51}$. It is encouraging to see that the catalytic efficiency for $\mathrm{H}_{2}$ evolution from artificial photocatalytic systems using mimics of the diiron subsite of $[\mathrm{FeFe}]-\mathrm{H}_{2}$ ase as catalysts has been increased from null to more than hundreds or thousands of turnover numbers (TON) under different irradiation conditions. In comparison to the efficient diiron active site of $[\mathrm{FeFe}]-\mathrm{H}_{2}$ ase in nature, however, no $[\mathrm{FeFe}]-\mathrm{H}_{2}$ ase mimic has been able to duplicate the high level of reactivity of natural $[\mathrm{FeFe}]-\mathrm{H}_{2}$ ase. Review of the literature indicates that the synthetic mimics of $[\mathrm{FeFe}]-\mathrm{H}_{2}$ ase reported thus far are mainly focused on the inorganic cofactor only, and the enzyme-like reaction that proceeds within restricted environments is to date poorly understood.

With this in mind, we initiated the study of a chitosanconfined mimic of the diiron subsite of $[\mathrm{FeFe}]-\mathrm{H}_{2}$ ase for $\mathrm{H}_{2}$ production. Chitosan is a naturally occurring polysaccharide containing a significant content of primary amines and hydroxyl groups ${ }^{52-54}$. When the amines are protonated by acids, chitosan bears a polycationic character. In view of the chelation and electrostatic interactions, we envision that chitosan may incorporate mimics of the diiron subsite of $[\mathrm{FeFe}]-\mathrm{H}_{2}$ ases intimately, as is the case of $[\mathrm{FeFe}]-\mathrm{H}_{2}$ ase, which is buried deeply within the protein matrix in nature. To avoid side-chain effects, the simplest mimic of the diiron subsite of $[\mathrm{FeFe}]-\mathrm{H}_{2}$ ases, $\left[\mathrm{Fe}_{2}(\mathrm{CO})_{6}(\mu\right.$-adt $\left.) \mathrm{CH}_{2} \mathrm{C}_{6} \mathrm{H}_{5}\right]\left[\mu \text {-adt }=\mathrm{N}\left(\mathrm{CH}_{2} \mathrm{~S}\right)_{2}\right]^{27,37}$, is selected as a catalyst (Fig. 1). The 3-mercaptopropionic acid (MPA)capped CdTe quantum dots (MPA-CdTe QDs), promising for $\mathrm{H}_{2}$ evolution in combination with a mimic of the diiron subsite of [FeFe] $-\mathrm{H}_{2}$ ase (ref. 45), are used as the photosensitizer. Herein, CdTe QDs are stabilized by MPA and their negatively charged surfaces ${ }^{55}$ preferably interact with cationic chitosan. Ascorbic acid $\left(\mathrm{H}_{2} \mathrm{~A}\right)$ serves as not only a proton source to protonate the

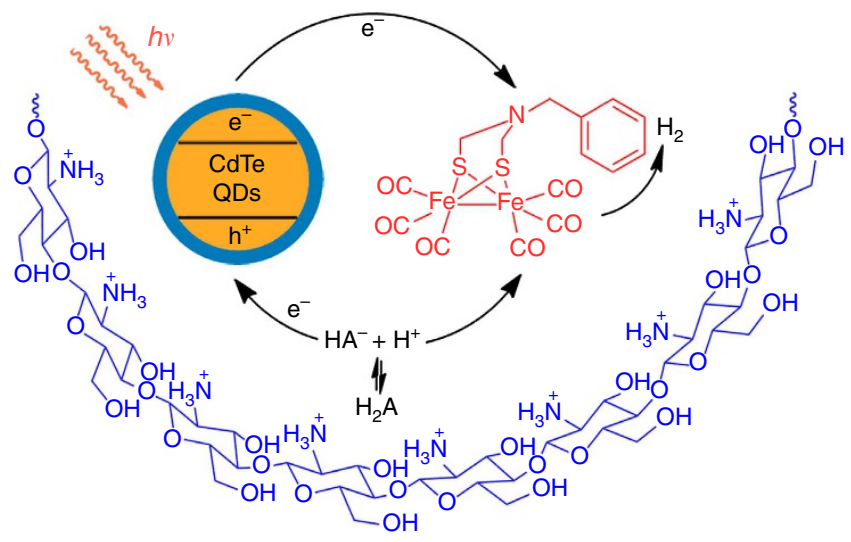

Figure 1 | Chitosan-confined $\mathbf{H}_{\mathbf{2}}$ photogeneration. A schematic describing the $\mathrm{H}_{2}$ photogeneration of a chitosan-confined mimic of the diiron subsite of $[\mathrm{FeFe}]-\mathrm{H}_{2}$ ase in the presence of $\mathrm{CdTe}$ quantum dots and $\mathrm{H}_{2} \mathrm{~A}$.

amines of chitosan and the catalytic intermediate of photoreduced mimic of the diiron subsite of $[\mathrm{FeFe}]-\mathrm{H}_{2}$ ase but also as a sacrificial electron donor to regenerate MPA-CdTe QDs for photocatalytic $\mathrm{H}_{2}$ production. Significantly, the self-assembled system that comprises chitosan, $\left[\mathrm{Fe}_{2}(\mathrm{CO})_{6}(\mu\right.$-adt $\left.) \mathrm{CH}_{2} \mathrm{C}_{6} \mathrm{H}_{5}\right]$, MPA-CdTe QDs and $\mathrm{H}_{2} \mathrm{~A}$ is capable of producing $\mathrm{H}_{2}$ with TON of up to $(5.28 \pm 0.17) \times 10^{4}$ and initial TOF of $1.40 \pm$ $0.22 \mathrm{~s}^{-1}$ with respect to $\left[\mathrm{Fe}_{2}(\mathrm{CO})_{6}(\mu\right.$-adt $\left.) \mathrm{CH}_{2} \mathrm{C}_{6} \mathrm{H}_{5}\right]$ catalyst under visible light irradiation $(\lambda>400 \mathrm{~nm})$. The catalytic stability is enhanced from 8 to $60 \mathrm{~h}$ and the catalytic activity is over $4.16 \times 10^{3}$-fold higher than that of the same system without chitosan. The activity and stability are, to the best of our knowledge, the highest to date for light-driven catalytic $\mathrm{H}_{2}$ evolution from mimics of the diiron subsite of $[\mathrm{FeFe}]-\mathrm{H}_{2}$ ase.

\section{Results}

The photocatalytic activity of $\mathbf{H}_{2}$ evolution. An initial photocatalytic experiment of $\left[\mathrm{Fe}_{2}(\mathrm{CO})_{6}(\mu\right.$-adt $\left.) \mathrm{CH}_{2} \mathrm{C}_{6} \mathrm{H}_{5}\right]$ catalyst with MPA-CdTe QDs was evaluated in the absence of chitosan. To keep the solubility of $\left[\mathrm{Fe}_{2}(\mathrm{CO})_{6}(\mu\right.$-adt $\left.) \mathrm{CH}_{2} \mathrm{C}_{6} \mathrm{H}_{5}\right]$ catalyst throughout the experiment, we carried out the reaction in a mixture of methanol and water. The anaerobic solution, containing $\left[\mathrm{Fe}_{2}(\mathrm{CO})_{6}(\mu\right.$-adt $\left.) \mathrm{CH}_{2} \mathrm{C}_{6} \mathrm{H}_{5}\right]$ catalyst $\left(1.00 \times 10^{-5} \mathrm{moll}^{-1}\right)$, MPACdTe QDs $\left(0.86 \times 10^{-6} \mathrm{moll}^{-1}\right)$, along with $\mathrm{H}_{2} \mathrm{~A}\left(0.10 \mathrm{moll}^{-1}\right)$, was irradiated by light-emitting diodes $(\lambda=410 \mathrm{~nm})$ at room temperature, where the best ratio of methanol to water was found to be 1:3 (v-v) (Supplementary Fig. S1). The photoproduct of $\mathrm{H}_{2}$ was characterized by gas chromatography (GC) analysis with methane as the internal standard. The time course showed that the amount of $\mathrm{H}_{2}$ increased in the first $4 \mathrm{~h}$ and then leveled off, yielding a TON of only $1.74 \pm 0.06$ based on $\left[\mathrm{Fe}_{2}(\mathrm{CO})_{6}(\mu\right.$-adt $)$ $\mathrm{CH}_{2} \mathrm{C}_{6} \mathrm{H}_{5}$ ] catalyst (Fig. 2a, line A). In sharp contrast, the catalytic performance of the same solution was improved significantly in the presence of $1.0 \mathrm{gl}^{-1}$ of chitosan. Line B in Fig. 2a shows the $\mathrm{H}_{2}$ production over time from the mixture under visible light irradiation. The amount of $\mathrm{H}_{2}$ reached $1.27 \pm 0.01 \mathrm{ml}$ $(\mathrm{TON}=569 \pm 2)$ within $10 \mathrm{~h}$ of irradiation, and the rate of $\mathrm{H}_{2}$ evolution was almost linear even after $10 \mathrm{~h}$ of irradiation. Control experiments further proved that the components in the system, $\left[\mathrm{Fe}_{2}(\mathrm{CO})_{6}(\mu\right.$-adt $\left.) \mathrm{CH}_{2} \mathrm{C}_{6} \mathrm{H}_{5}\right]$ catalyst, MPA-CdTe QDs, $\mathrm{H}_{2} \mathrm{~A}$, chitosan or light are all essential for efficient $\mathrm{H}_{2}$ generation. The absence of $\left[\mathrm{Fe}_{2}(\mathrm{CO})_{6}(\mu\right.$-adt $\left.) \mathrm{CH}_{2} \mathrm{C}_{6} \mathrm{H}_{5}\right]$ catalyst led to the rate of $\mathrm{H}_{2}$ evolution dropping dramatically and no $\mathrm{H}_{2}$ could be detected when either MPA-CdTe QDs or $\mathrm{H}_{2} \mathrm{~A}$ was absent from the reaction system with chitosan (Supplementary Fig. S2). 

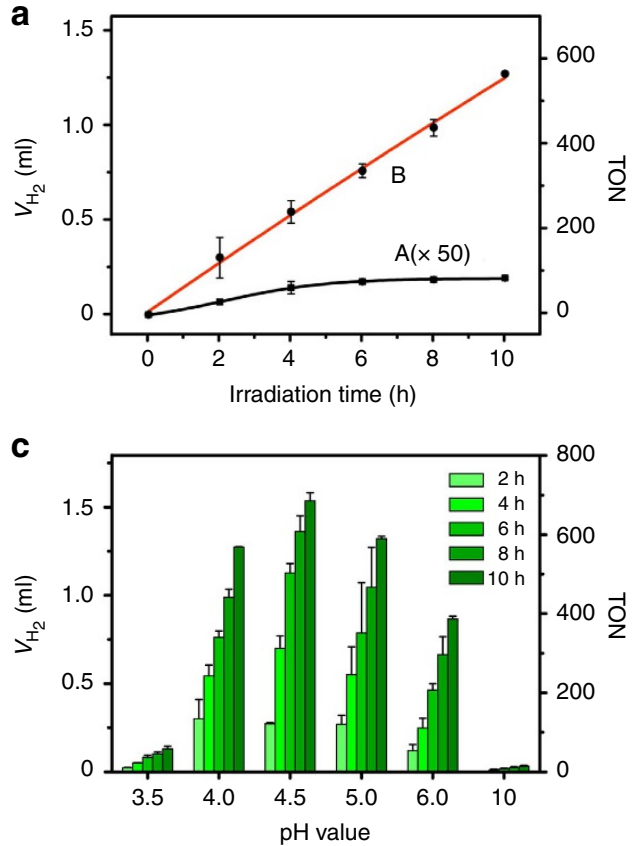
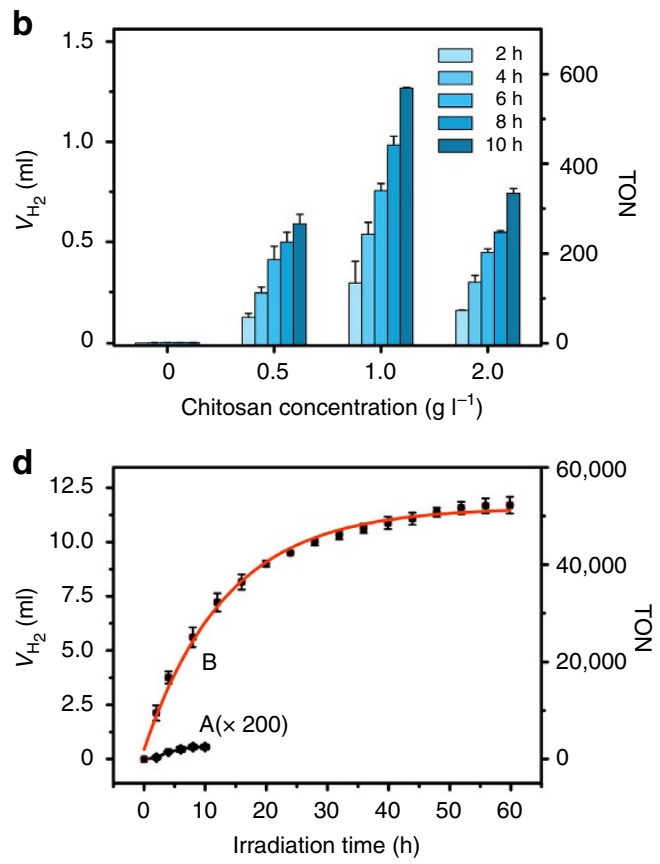

Figure 2 | $\mathbf{H}_{\mathbf{2}}$ evolution under visible light irradiation. (a) $\mathrm{H}_{2}$ evolution in the absence (A) and presence (B) of chitosan (1.0 $\mathrm{g} \mathrm{I}^{-1}$ ), containing MPA-CdTe QDs $\left(0.86 \times 10^{-6} \mathrm{moll}^{-1}\right),\left[\mathrm{Fe}_{2}(\mathrm{CO})_{6}(\mu\right.$-adt $\left.) \mathrm{CH}_{2} \mathrm{C}_{6} \mathrm{H}_{5}\right]$ catalyst $\left(1.00 \times 10^{-5} \mathrm{moll}^{-1}\right)$ and $\mathrm{H}_{2} \mathrm{~A}(0.10 \mathrm{moll}-1)$ in methanol/water $\left(1: 3 \mathrm{v}\right.$-v); (b) $\mathrm{H}_{2}$ evolution as a function of chitosan concentrations, containing MPA-CdTe QDs $\left(0.86 \times 10^{-6} \mathrm{moll}^{-1}\right),\left[\mathrm{Fe}_{2}(\mathrm{CO})_{6}(\mu\right.$-adt $\left.) \mathrm{CH}_{2} \mathrm{C}_{6} \mathrm{H}_{5}\right]$ catalyst $\left(1.00 \times 10^{-5} \mathrm{moll}^{-1}\right)$ and $\mathrm{H}_{2} \mathrm{~A}\left(0.10 \mathrm{moll}^{-1}\right)$ in methanol/water $(1: 3 \mathrm{v}-\mathrm{v}) ;(\mathbf{c}) \mathrm{H}_{2}$ evolution at various pH values, containing MPA-CdTe QDs $\left(0.86 \times 10^{-6} \mathrm{moll}^{-1}\right),\left[\mathrm{Fe}_{2}(\mathrm{CO})_{6}(\mu\right.$-adt $\left.) \mathrm{CH}_{2} \mathrm{C}_{6} \mathrm{H}_{5}\right]\left(1.00 \times 10^{-5} \mathrm{moll}^{-1}\right), \mathrm{H}_{2} \mathrm{~A}\left(0.10 \mathrm{moll}^{-1}\right)$ and chitosan $\left(1.0 \mathrm{~g} \mathrm{I}{ }^{-1}\right)$ in methanol/water $(1: 3 \mathrm{v}$-v $)$; (d) $\mathrm{H}_{2}$ evolution under the optimized conditions in the absence $(A)$ and presence $(B)$ of chitosan, containing MPA-CdTe QDs $\left(1.71 \times 10^{-6}\right.$ mol I-1), $\left[\mathrm{Fe}_{2}(\mathrm{CO})_{6}(\mu\right.$-adt $\left.) \mathrm{CH}_{2} \mathrm{C}_{6} \mathrm{H}_{5}\right]\left(1.00 \times 10^{-6} \mathrm{moll}^{-1}\right)$ and $\mathrm{H}_{2} \mathrm{~A}\left(0.20 \mathrm{moll} \mathrm{I}^{-1}\right)$ in methanol/water $(1: 3 \mathrm{v}-\mathrm{v})$ at $\mathrm{pH}$ 4.5. Error bars represent mean $\pm \mathrm{s}$.d. of parallel experiments.

The difference in the catalytic activity (1.74 versus 569$)$ and stability ( 4 versus $10 \mathrm{~h}$ ) for the systems with and without chitosan under the same condition implies that chitosan has a key role in the photocatalytic $\mathrm{H}_{2}$ evolution.

Furthermore, the amounts of chitosan together with MPA-CdTe QDs and $\left[\mathrm{Fe}_{2}(\mathrm{CO})_{6}(\mu\right.$-adt $\left.) \mathrm{CH}_{2} \mathrm{C}_{6} \mathrm{H}_{5}\right]$ catalyst were carefully investigated to optimize the reaction. Note that $1.0 \mathrm{gl}^{-1}$ chitosan is the best concentration to achieve the highest TON of the assembled system for $\mathrm{H}_{2}$ evolution under a given $\mathrm{pH}$ condition (Fig. 2b). And the smaller size of MPA-CdTe QDs that is emissive at shorter wavelength gives rise to the higher TON for the photocatalytic $\mathrm{H}_{2}$ evolution system (Supplementary Fig. S3). The highest TON was obtained in the presence of MPA-CdTe QDs Green $(2.8 \mathrm{~nm})$ (Supplementary Table S1). As the conduction band energy of MPACdTe QDs Green is over $-2.0 \mathrm{~V}$, we could detect a small amount of $\mathrm{H}_{2}$ from the system without catalyst (Supplementary Fig. S2). Under the same condition, that is, $10 \mathrm{ml}$ methanol/water solution $(1: 3, \mathrm{v}-\mathrm{v})$ containing chitosan $\left(1.0 \mathrm{gl}^{-1}\right)$, MPA-CdTe QDs $\left(0.86 \times 10^{-6}\right.$ moll $\left.{ }^{-1}\right)$ and $\mathrm{H}_{2} \mathrm{~A}\left(0.10 \mathrm{moll}^{-1}\right)$ at $\mathrm{pH} 4.0$, the amount of $\mathrm{H}_{2}$ was $6.61 \pm 0.48 \mu \mathrm{l}$ per $10 \mathrm{~h}$ in the absence of catalyst. However, the presence of catalyst, $\left[\mathrm{Fe}_{2}(\mathrm{CO})_{6}(\mu\right.$-adt $\left.) \mathrm{CH}_{2} \mathrm{C}_{6} \mathrm{H}_{5}\right] \quad\left(1.00 \times 10^{-5}\right.$ moll $\left.{ }^{-1}\right)$, resulted in $\mathrm{H}_{2}$ evolution efficiently $(1.27 \pm 0.01 \mathrm{ml}$ per $10 \mathrm{~h})$. Moreover, the rate of $\mathrm{H}_{2}$ evolution increased as a function of the concentration of $\left[\mathrm{Fe}_{2}(\mathrm{CO})_{6}(\mu\right.$-adt $\left.) \mathrm{CH}_{2} \mathrm{C}_{6} \mathrm{H}_{5}\right]$ catalyst (Supplementary Fig. S4). When the concentration of the catalyst was higher than $1.00 \times 10^{-5} \mathrm{moll}^{-1}$, where the ideal concentration of MPA-CdTe QDs was $1.71 \times 10^{-6} \mathrm{moll}^{-1}$ (Supplementary Fig. S5), the rate of $\mathrm{H}_{2}$ evolution would be no longer linear. In this situation, the highest TON value was achieved at $1.00 \times 10^{-6}$ moll ${ }^{-1}$ of $\left[\mathrm{Fe}_{2}(\mathrm{CO})_{6}\left(\mu\right.\right.$-adt) $\left.\mathrm{CH}_{2} \mathrm{C}_{6} \mathrm{H}_{5}\right]$ (Supplementary Fig. S4), the optimal ratio of MPA-CdTe QDs to $\left[\mathrm{Fe}_{2}(\mathrm{CO})_{6}(\mu\right.$-adt $\left.) \mathrm{CH}_{2} \mathrm{C}_{6} \mathrm{H}_{5}\right]$ catalyst is therefore $1.7: 1$.
It was worth noting that the $\mathrm{pH}$ value is the most important factor that governs the performance of photocatalytic $\mathrm{H}_{2}$ evolution. Figure $2 \mathrm{c}$ shows $\mathrm{pH}$ effect on the $\mathrm{H}_{2}$ evolution under the same concentrations of $\left[\mathrm{Fe}_{2}(\mathrm{CO})_{6}(\mu-\mathrm{adt}) \mathrm{CH}_{2} \mathrm{C}_{6} \mathrm{H}_{5}\right]$ catalyst, MPA-CdTe QDs, chitosan and $\mathrm{H}_{2} \mathrm{~A}$. A maximal rate of $\mathrm{H}_{2}$ evolution was achieved at $\mathrm{pH} 4.5$, whereas significant amounts of $\mathrm{H}_{2}$ were also observed at either lower or higher $\mathrm{pH}$ value. This $\mathrm{pH}$-dependent effect should be related to the solubility of chitosan, the stability of MPA-CdTe QDs and the equilibrium of $\mathrm{H}_{2} \mathrm{~A}=\mathrm{H}^{+}+\mathrm{HA}^{-}$. At a higher $\mathrm{pH}$ value, the lack of protonatable amine groups at $\mathrm{C}-2$ position of the glucosamine residue $^{54}$ decreases the solubility of chitosan and thus lowers the ability of chitosan to function as an environmental confinement. On the other hand, the protons in the solution with lower $\mathrm{pH}$ would suppress the equilibrium to generate enough sacrificial electron donor of $\mathrm{HA}^{-}$for $\mathrm{H}_{2}$ evolution ${ }^{45}$, and at the same time the MPA ligands would dissociate from the surface of CdTe QDs at a $\mathrm{pH}$ value of the solution lower than 4.0, resulting in precipitation and defects that could capture the excited electrons on the surface of the MPA-CdTe species ${ }^{55,56}$.

Considering all above experimental trials, we carried out the reaction under the optimized condition, that is, $10 \mathrm{ml}$ methanol/ water solution $\left(1: 3 \mathrm{v}\right.$-v) containing $\left[\mathrm{Fe}_{2}(\mathrm{CO})_{6}(\mu\right.$-adt $\left.) \mathrm{CH}_{2} \mathrm{C}_{6} \mathrm{H}_{5}\right]$ catalyst $\left(1.00 \times 10^{-6} \mathrm{moll}^{-1}\right)$, MPA-CdTe QDs $\left(1.71 \times 10^{-6}\right.$ moll $\left.{ }^{-1}\right), \mathrm{H}_{2} \mathrm{~A}\left(0.10 \mathrm{moll}^{-1}\right)$ and chitosan $\left(1.0 \mathrm{gl}^{-1}\right)$ at $\mathrm{pH} 4.5$. More than $1.04 \pm 0.04 \mathrm{ml}$ of $\mathrm{H}_{2}$ was produced during $10 \mathrm{~h}$ of irradiation with visible light $(\lambda=410 \mathrm{~nm}$ ) (Supplementary Fig. S4). Even more amounts of $\mathrm{H}_{2}$ in a total of $11.83 \pm 0.39 \mathrm{ml}$ were obtained when the concentration of $\mathrm{H}_{2} \mathrm{~A}$ was further increased to $0.20 \mathrm{moll}^{-1}$ (Supplementary Fig. S6). This result means that more than $(5.28 \pm 0.17) \times 10^{4}$ equivalents of $\mathrm{H}_{2}$ per $\left[\mathrm{Fe}_{2}(\mathrm{CO})_{6}(\mu\right.$-adt $\left.) \mathrm{CH}_{2} \mathrm{C}_{6} \mathrm{H}_{5}\right]$ catalyst are generated over $60 \mathrm{~h}$ of 
irradiation (Fig. 2d), with an initial TOF of $1.40 \pm 0.22 \mathrm{H}_{2}$ per catalyst per second in the first $2 \mathrm{~h}$ (Supplementary Fig. S7). The catalytic activity is improved $4.16 \times 10^{3}$ folds that of the same system without chitosan.

Interaction of catalytic components with chitosan. The enhanced durability and efficiency is possibly due to the strong interaction and close contact between the MPA-CdTe QDs, $\left[\mathrm{Fe}_{2}(\mathrm{CO})_{6}(\mu\right.$-adt $\left.) \mathrm{CH}_{2} \mathrm{C}_{6} \mathrm{H}_{5}\right]$ catalyst and $\mathrm{H}_{2} \mathrm{~A}$ in the chitosanconfined environment (Fig. 1). The encapsulation of the MPACdTe QDs by chitosan was well evidenced by high-resolution transmission electron microscopy. The high-resolution transmission electron microscopy images of the MPA-CdTe QDs reveal that chitosan associates with the MPA-CdTe QDs to form self-assemblies on a large scale, and their average size is in the range of $50 \sim 200 \mathrm{~nm}$ (Fig. 3). Even after $10 \mathrm{~h}$ of irradiation, the shape and composition of the self-assemblies with well-crystallized lattices of MPA-CdTe QDs for $\mathrm{H}_{2}$ evolution remained unchanged. This finding is different from that observed in the reaction system without chitosan (Supplementary Fig. S8). Although no obvious spectral change could be detected in the UV-vis absorption spectra of chitosan and MPA-CdTe QDs as well as their mixture (Supplementary Fig. S9), the photoluminescent intensity of the MPA-CdTe QDs increased and blueshifted greatly with the introduction of chitosan (Fig. 4a), and simultaneously the photoluminescent lifetime of the MPA-CdTe QDs enhanced from 10.9 to 18.3 ns when the concentration of chitosan was varied from 0 to $1.0 \mathrm{gl}^{-1}$ at $\mathrm{pH} 4.5$ (Fig. 4b). It is known that the photoluminescence of QDs is very sensitive to a $\mathrm{pH}$ value of solution ${ }^{55}$. When the $\mathrm{pH}$ value of an aqueous solution of the MPA-CdTe was adjusted to 4.5, the maximal photoluminescence was found to shift to lower energy at $575 \mathrm{~nm}$ accompanying with decreases in the photoluminescent intensity and lifetime (Table 1). The observations are due to the aggregation of the MPA-CdTe QDs to form larger ones ${ }^{55,56}$. The blue-shift from 575 to $557 \mathrm{~nm}$ in the current study suggests that chitosan stabilizes the CdTe QDs and prevents them from forming larger aggregators. More strikingly, the photoluminescence quantum yield of the MPA-CdTe QDs increased from $5.1 \%$ to $38.3 \%$ when chitosan was presented in the solution of methanol/water $(1: 3, \mathrm{v}-\mathrm{v})$ at $\mathrm{pH} 4.5$. The photoluminescent enhancement in intensity, lifetime and quantum yield indicates that chitosan wraps the MPA-CdTe QDs by coordination to cadmium ions of CdTe QDs, and thus suppresses, to some extent, the non-radiative decay of MPACdTe QDs. The similar effect was also observed by Yang and Gao et al. ${ }^{57}$ with the addition of poly(acrylic acid) into the aqueous solution of CdTe QDs.
The interaction of $\left[\mathrm{Fe}_{2}(\mathrm{CO})_{6}(\mu\right.$-adt $\left.) \mathrm{CH}_{2} \mathrm{C}_{6} \mathrm{H}_{5}\right]$ catalyst with chitosan was carefully examined and is shown in Fig. 5. No absorbance could be detected from $\left[\mathrm{Fe}_{2}(\mathrm{CO})_{6}(\mu\right.$-adt $\left.) \mathrm{CH}_{2} \mathrm{C}_{6} \mathrm{H}_{5}\right]$ catalyst in pure water but with continuous sonication of insoluble $\left[\mathrm{Fe}_{2}(\mathrm{CO})_{6}(\mu\right.$-adt $\left.) \mathrm{CH}_{2} \mathrm{C}_{6} \mathrm{H}_{5}\right]$ catalyst and a chitosan $\left(1.0 \mathrm{gl}^{-1}\right)$ solution in methanol/water $(1: 3, \mathrm{v}-\mathrm{v})$ at $\mathrm{pH} 4.5$ its solubility and absorbance were remarkably enhanced with the formation of a coloured solution. Alternatively, progressive addition of $\left[\mathrm{Fe}_{2}(\mathrm{CO})_{6}(\mu\right.$-adt $\left.) \mathrm{CH}_{2} \mathrm{C}_{6} \mathrm{H}_{5}\right]$ catalyst in dichloromethane into a solution of chitosan $\left(1.0 \mathrm{gl}^{-1}\right)$ in methanol/water $(1: 3, \mathrm{v}-\mathrm{v})$ at $\mathrm{pH}$ 4.5 resulted in an increase of absorption band at $336 \mathrm{~nm}$ remarkably. As compared with the same system without chitosan in methanol/water (1:3, v-v) at $\mathrm{pH} 4.5$ (Supplementary Fig. S10), the increment of the absorbance at $336 \mathrm{~nm}$ is much greater. The results indicate that water-insoluble $\left[\mathrm{Fe}_{2}(\mathrm{CO})_{6}(\mu\right.$-adt $\left.) \mathrm{CH}_{2} \mathrm{C}_{6} \mathrm{H}_{5}\right]$ catalyst is incorporated into the chitosan solution. The absorbance at $336 \mathrm{~nm}$ obeys the Beer's law showing that $\left[\mathrm{Fe}_{2}(\mathrm{CO})_{6}\right.$ ( $\mu$-adt) $\left.\mathrm{CH}_{2} \mathrm{C}_{6} \mathrm{H}_{5}\right]$ catalyst is well dispersed in the chitosan solution at $\mathrm{pH}$ 4.5. Decreasing the $\mathrm{pH}$ of the solution has no noticeable influence on the absorption spectra, suggesting that $\left[\mathrm{Fe}_{2}(\mathrm{CO})_{6}(\mu\right.$-adt $\left.) \mathrm{CH}_{2} \mathrm{C}_{6} \mathrm{H}_{5}\right]$ catalyst does not react with protons under the experimental condition.

The interaction of $\left[\mathrm{Fe}_{2}(\mathrm{CO})_{6}(\mu\right.$-adt $\left.) \mathrm{CH}_{2} \mathrm{C}_{6} \mathrm{H}_{5}\right]$ catalyst and chitosan was further confirmed by dialysis experiments. As depicted in the schematic representation of Fig. 5, $1.00 \times$ $10^{-4} \mathrm{moll}^{-1}$ of $\left[\mathrm{Fe}_{2}(\mathrm{CO})_{6}(\mu\right.$-adt $\left.) \mathrm{CH}_{2} \mathrm{C}_{6} \mathrm{H}_{5}\right]$ catalyst was put into dialysis bag $\mathrm{A}$, and the same amount of $\left[\mathrm{Fe}_{2}(\mathrm{CO})_{6}(\mu\right.$-adt $)$ $\mathrm{CH}_{2} \mathrm{C}_{6} \mathrm{H}_{5}$ ] catalyst together with $1.0 \mathrm{gl}^{-1}$ of chitosan were in dialysis bag $\mathrm{B}$, respectively. Along with the time, the diffusion rate of the catalyst to the outside solution from dialysis bag B was noted much slower than that from dialysis bag $A$, and thus leading to the concentration change of the catalyst from dialysis bag $\mathrm{B}$ smaller than that from dialysis bag $\mathrm{A}$. These results imply the intimate interaction of chitosan and $\left[\mathrm{Fe}_{2}(\mathrm{CO})_{6}\right.$ $(\mu$-adt $\left.) \mathrm{CH}_{2} \mathrm{C}_{6} \mathrm{H}_{5}\right]$ catalyst.

The direct evidence on the interaction comes from electrochemical studies under nitrogen atmosphere. Note that the reduction potential of $\left[\mathrm{Fe}_{2}(\mathrm{CO})_{6}(\mu\right.$-adt $\left.) \mathrm{CH}_{2} \mathrm{C}_{6} \mathrm{H}_{5}\right]$ positively shifts from $-1.36 \mathrm{~V}$ versus $\mathrm{NHE}$ in acetonitrile to $-1.10 \mathrm{~V}$ versus NHE in methanol/water $(1: 1, \quad \mathrm{v}-\mathrm{v})$ at $\mathrm{pH} \quad 4.5$ (Supplementary Fig. S11), which is attributed to the reduction of $\mathrm{Fe}^{\mathrm{I}} \mathrm{Fe}^{\mathrm{I}}$ to $\mathrm{Fe}^{\mathrm{I}} \mathrm{Fe}^{0}$ of $\left[\mathrm{Fe}_{2}(\mathrm{CO})_{6}(\mu\right.$-adt $\left.) \mathrm{CH}_{2} \mathrm{C}_{6} \mathrm{H}_{5}\right]$ catalyst ${ }^{27-29}$. Although the reduction potential of $\left[\mathrm{Fe}_{2}(\mathrm{CO})_{6}(\mu\right.$-adt $\left.) \mathrm{CH}_{2} \mathrm{C}_{6} \mathrm{H}_{5}\right]$ remained unchanged with the addition of chitosan at $\mathrm{pH} 4.5$ (Table 1), the cyclic voltammogram of a solution with or without chitosan, containing the same amounts of $\left[\mathrm{Fe}_{2}(\mathrm{CO})_{6}(\mu\right.$-adt $)$ $\mathrm{CH}_{2} \mathrm{C}_{6} \mathrm{H}_{5}$ ] catalyst, displayed different electrochemical responses on progressive addition of acetic acid (HOAc). Given in Fig. 5 is the cyclic voltammetry of $\left[\mathrm{Fe}_{2}(\mathrm{CO})_{6}(\mu\right.$-adt $\left.) \mathrm{CH}_{2} \mathrm{C}_{6} \mathrm{H}_{5}\right]$ catalyst
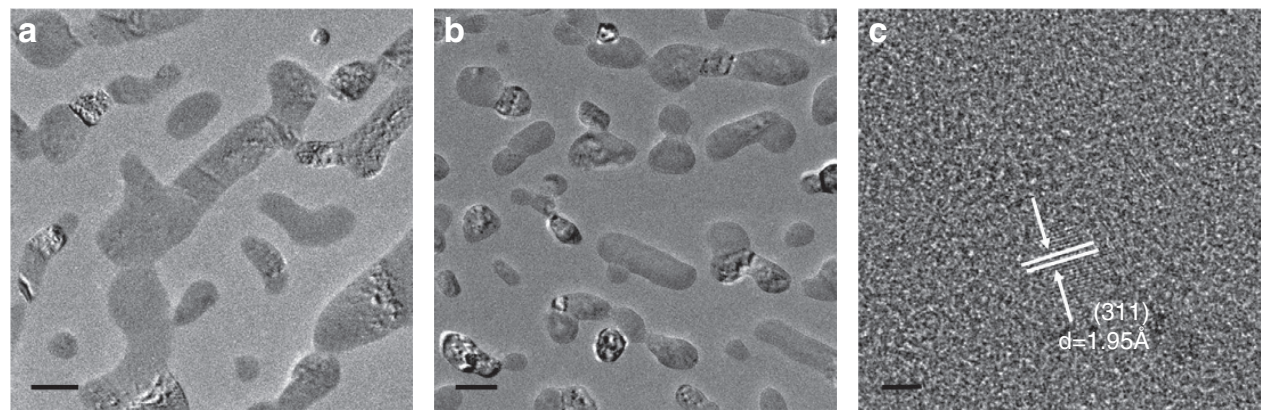

Figure 3 | Interaction of MPA-CdTe QDs with chitosan. High-resolution transmission electron microscopy images of MPA-CdTe QDs and chitosan in the reaction system before irradiation (a) (bar scale, $200 \mathrm{~nm}$ ) and after irradiation for $10 \mathrm{~h}$ (b) (bar scale, $200 \mathrm{~nm}$ ). The MPA-CdTe QDs inside chitosan after irradiation for $10 \mathrm{~h}$ (c) (bar scale, $2 \mathrm{~nm}$ ). 

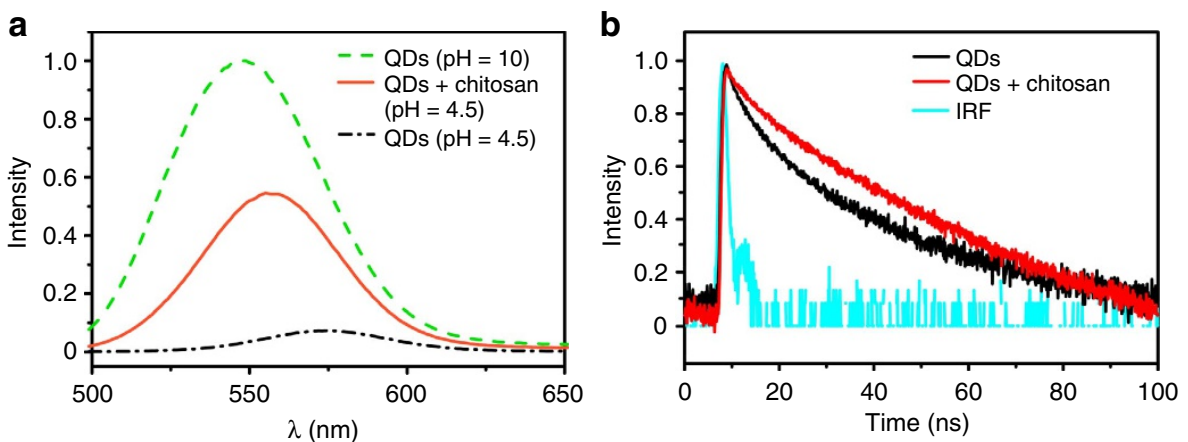

Figure 4 | Photoluminescence properties of MPA-CdTe QDs with chitosan. (a) Photoluminescence spectra of MPA-CdTe QDs $\left(0.86 \times 10^{-6}\right.$ mol I ${ }^{-1}$ ) at $\mathrm{pH} 10$ and $\mathrm{pH} 4.5$, and the photoluminescence of MPA-CdTe in the presence of chitosan at $\mathrm{pH} 4.5$, in methanol/water (1:3 v-v). (b) Photoluminescence lifetime of MPA-CdTe QDs in the absence and presence of chitosan $\left(1.0 \mathrm{gl}^{-1}\right)$ at $\mathrm{pH} 4.5$. The signal of IRF (blue) is the response of the instrument.

Table 1 | Spectroscopic and electrochemical properties of the systems for $\mathbf{H}_{2}$ evolution.

\begin{tabular}{|c|c|c|c|c|c|c|c|c|}
\hline $\mathrm{H}_{2}$ evolution system & ${ }^{\star} \lambda(\mathrm{nm})$ & ${ }^{\star} \tau$ (ns) & ${ }^{\star} \Phi(\%)$ & ${ }^{\dagger} E_{00}(\mathrm{eV})$ & ${ }^{\ddagger} k_{\mathrm{q}}\left(1 \mathrm{~mol}^{-1}\right)$ & ${ }^{\S} E_{\text {red }}(e V)$ & $\S_{\Delta G^{0}(\mathrm{eV})}$ & ${ }^{\|}$TON \\
\hline CdTe QDs & 575 & 10.9 & 5.1 & 2.16 & $(9.95 \pm 0.67) \times 10^{3}$ & -1.10 & -0.97 & $12.7 \pm 1.3$ \\
\hline CdTe QDs + chitosan & 557 & 18.3 & 38.3 & 2.23 & $(2.26 \pm 0.02) \times 10^{4}$ & -1.10 & -1.04 & $(5.28 \pm 0.17) \times 10^{4}$ \\
\hline
\end{tabular}

TON, turnover number; QDs, quantum dots.

*Photoluminescent wavelength $(\lambda)$, lifetime $(\tau)$ and quantum yield $(\Phi)$ of the MPA-CdTe QDs in methanol/water $(1: 3, v-v)$ at $\mathrm{pH} 4.5$. The photoluminescent quantum yield $(\Phi)$ was determined by equation $\Phi=\left(I / I_{s}\right)\left(A_{s} / A\right)\left(n / n_{s}\right)^{2} \Phi_{s}$, where $l$ is the luminescent intensity, $A$ is the absorbance, $n$ is the refractive index of the solvent. Rhodamine 101 was used as the standard with $\Phi_{s}$ (\%) being 100 in ethanol ${ }^{60}$.

TThe excited-state energy $\left(E_{00}\right)$ of the MPA-CdTe QDs was determined by the equation $E_{00}=h c / \lambda$

TThe quenching constant $\left(k_{q}\right)$ of the MPA-CdTe QDs by $\left[\mathrm{Fe}_{2}(\mathrm{CO})_{6}(\mu\right.$-adt $\left.) \mathrm{CH}_{2} \mathrm{C}_{6} \mathrm{H}_{5}\right]$ catalyst was determined by Stern-Volmer equation: $k_{q}=\left[I_{0} / I_{p}-1\right] /[Q], I$ is the photoluminescent intensity of the MPA-CdTe QDs, $[Q]$ is the concentration of $\left[\mathrm{Fe}_{2}(\mathrm{CO})_{6}(\mu\right.$-adt $\left.) \mathrm{CH}_{2} \mathrm{C}_{6} \mathrm{H}_{5}\right]$ catalyst.

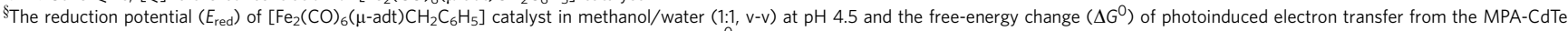
QDs to $\left[\mathrm{Fe}_{2}(\mathrm{CO})_{6}\left(\mu\right.\right.$-adt) $\left.\mathrm{CH}_{2} \mathrm{C}_{6} \mathrm{H}_{5}\right]$ catalyst was determined by Rehm-Weller equation $\Delta G^{0}=E_{\mathrm{vb}}-E_{\mathrm{red}}-E_{00}$, where the valence-band energy level ( $E_{\mathrm{vb}}$ ) of the MPA-CdTe QDs is $0.09 \mathrm{~V}$ (ref. 58 ). IIThe TON of photocatalytic $\mathrm{H}_{2}$ evolution under the optimized condition.

in the absence and presence of HOAc. The current intensity of the reduction peak increases with the acid concentration, the characteristic of proton reduction ${ }^{10-12}$. On reversing the scan following the reductions at $-1.26 \mathrm{~V}$ versus NHE, a reproducible curve-crossing was clearly observed for $\left[\mathrm{Fe}_{2}(\mathrm{CO})_{6}(\mu\right.$-adt $)$ $\mathrm{CH}_{2} \mathrm{C}_{6} \mathrm{H}_{5}$ ] catalyst resulting in the buildup of current response at $-1.00 \mathrm{~V}$ versus NHE. The peak current at $-1.00 \mathrm{~V}$ is proportional to the square root of the scan rate (Supplementary Fig. S12), suggesting that the electrochemical processes are diffusion-controlled and excluding the possibility of the curvecrossing event arising from electrode deposition. Moreover, the current height of the $-1.00 \mathrm{~V}$ events increases with increasing acid concentrations. Its dependence on both potential scan rate and acid concentration reveals that a larger fraction of the starting material is regenerated at reaction times that correspond to potentials positive of the curve-crossing. Following from the electrochemical studies of a mimic of the diiron subunit of $[\mathrm{FeFe}]-\mathrm{H}_{2}$ ase by Darensbourg and co-workers ${ }^{28}$, we suppose that the curve-crossing electrochemical responses are an integral property of the electroactive $(-1.10 \mathrm{~V})$ species, presumed to be the $\mathrm{Fe}^{\mathrm{I}} \mathrm{Fe}$ to $\mathrm{Fe}^{\mathrm{I}} \mathrm{Fe}^{0}$ reduction, for which a rapid chemical reaction, that is, protonation of the $\mathrm{Fe}^{\mathrm{I}} \mathrm{Fe}^{0}$ species produces the increased current at more negative potential. The presence of a more easily reproducible product or intermediate as seen in the reverse electrochemical scan suggests that a subsequent slow chemical reaction produces an intermediate of sufficient stability to build up in solution and migrate back to the electrode for reduction at a more positive potential. Evidently, the system with chitosan yielded much more intermediate species at $-1.00 \mathrm{~V}$ than that working in the absence of chitosan under the same concentration of $\left[\mathrm{Fe}_{2}(\mathrm{CO})_{6}(\mu\right.$-adt $\left.) \mathrm{CH}_{2} \mathrm{C}_{6} \mathrm{H}_{5}\right]$ catalyst, indicative of greater sensitivity and stability of the reduced species to acid concentration in the presence of chitosan.
In view of the sensitivity of the system to the $\mathrm{pH}$ value of solution, all of the interaction studies were carried out at $\mathrm{pH} 4.5$ to agree with the optimized condition. In the presence of chitosan, the absorption spectrum of the MPA-CdTe QDs and $\left[\mathrm{Fe}_{2}(\mathrm{CO})_{6}(\mu\right.$-adt $\left.) \mathrm{CH}_{2} \mathrm{C}_{6} \mathrm{H}_{5}\right]$ catalyst was the superposition of the MPA-CdTe QDs, chitosan and $\left[\mathrm{Fe}_{2}(\mathrm{CO})_{6}(\mu\right.$-adt $\left.) \mathrm{CH}_{2} \mathrm{C}_{6} \mathrm{H}_{5}\right]$ (Supplementary Fig. S9), but the photoluminescence of MPACdTe QDs was quenched by $\left[\mathrm{Fe}_{2}(\mathrm{CO})_{6}(\mu\right.$-adt $\left.) \mathrm{CH}_{2} \mathrm{C}_{6} \mathrm{H}_{5}\right]$ dramatically. As shown in Fig. 6, excitation of the characteristic absorption of MPA-CdTe QDs resulted in a maximal photoluminescence at $575 \mathrm{~nm}$ in methanol/water $(1: 3, \mathrm{v}-\mathrm{v})$ solution, which was quenched by $\left[\mathrm{Fe}_{2}(\mathrm{CO})_{6}(\mu\right.$-adt $\left.) \mathrm{CH}_{2} \mathrm{C}_{6} \mathrm{H}_{5}\right]$ with a rate constant of $(9.95 \pm 0.67) \times 10^{3} \mathrm{lmol}^{-1}$ (Table 1, Supplementary Fig. S13). When $1.0 \mathrm{gl}^{-1}$ of chitosan was presented in the solution, the photoluminescent maximum blue-shifted to $557 \mathrm{~nm}$ and the quenching rate constant increased to $(2.26 \pm 0.02) \times$ $10^{4} \mathrm{~mol}^{-1}$ (Table 1, Supplementary Fig. S13). Clearly, the interaction between the MPA-CdTe QDs and $\left[\mathrm{Fe}_{2}(\mathrm{CO})_{6}(\mu\right.$-adt $)$ $\mathrm{CH}_{2} \mathrm{C}_{6} \mathrm{H}_{5}$ ] catalyst is stronger in the self-assembled chitosan system than that in free solution.

As the spectral overlap of absorption of $\left[\mathrm{Fe}_{2}(\mathrm{CO})_{6}(\mu\right.$-adt $)$ $\mathrm{CH}_{2} \mathrm{C}_{6} \mathrm{H}_{5}$ ] catalyst and photoluminescence of MPA-CdTe QDs is rather small, the energy transfer from the excited MPA-CdTe QDs to $\left[\mathrm{Fe}_{2}(\mathrm{CO})_{6}(\mu\right.$-adt $\left.) \mathrm{CH}_{2} \mathrm{C}_{6} \mathrm{H}_{5}\right]$ catalyst would be negligible. Electron transfer from the excited MPA-CdTe QDs to $\left[\mathrm{Fe}_{2}(\mathrm{CO})_{6}(\mu\right.$-adt $\left.) \mathrm{CH}_{2} \mathrm{C}_{6} \mathrm{H}_{5}\right]$ catalyst is therefore responsible for the photoluminescence quenching of the MPA-CdTe QDs. Combining electrochemical and spectroscopic studies (Table 1), we estimated the free-energy change of electron transfer reaction from the excited MPA-CdTe QDs to $\left[\mathrm{Fe}_{2}(\mathrm{CO})_{6}(\mu\right.$-adt $\left.) \mathrm{CH}_{2} \mathrm{C}_{6} \mathrm{H}_{5}\right]$ catalyst. According to the valence-band energy level $\left(E_{\mathrm{vb}}\right)$ of MPA-CdTe QDs, which is $0.09 \mathrm{~V}$ (all potentials discussed here are versus $\mathrm{NHE})^{58}$ and the reduction potential $\left(E_{\text {red }}\right)$ of 

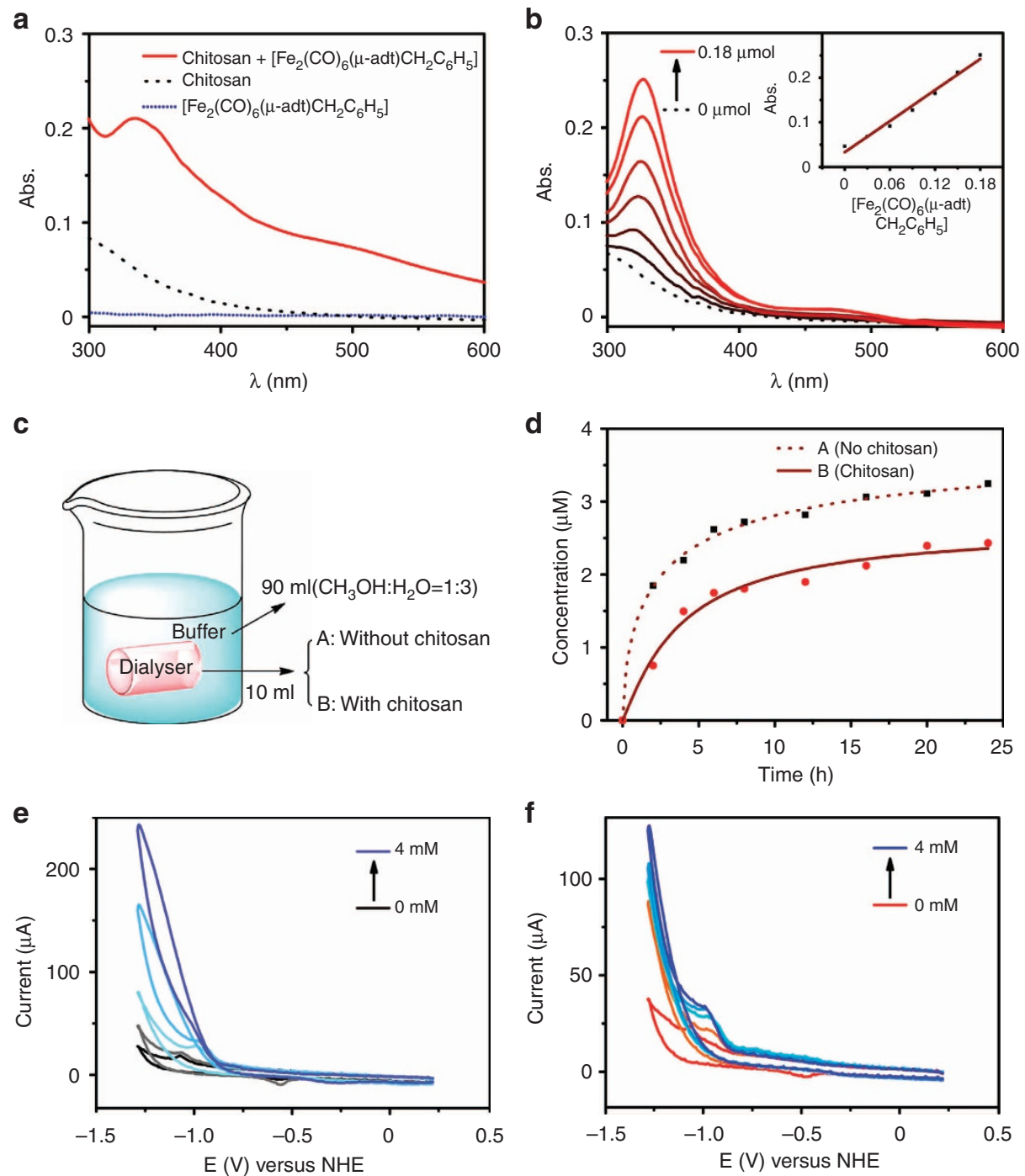

Figure 5 | Interaction of $\left[\mathrm{Fe}_{\mathbf{2}}(\mathbf{C O})_{\mathbf{6}}\left(\boldsymbol{\mu}\right.\right.$-adt) $\left.\mathbf{C H}_{\mathbf{2}} \mathbf{C}_{\mathbf{6}} \mathbf{H}_{\mathbf{5}}\right]$ catalyst with chitosan. (a) The absorption spectra of $\left[\mathrm{Fe}_{2}(\mathrm{CO})_{6}\left(\mu\right.\right.$-adt) $\left.\mathrm{CH}_{2} \mathrm{C}_{6} \mathrm{H}_{5}\right]$ catalyst $\left(3.00 \times 10^{-7} \mathrm{~mol}\right)$ in water at $\mathrm{pH} 4.5$, an chitosan solution $\left(1.0 \mathrm{gl}^{-1}\right)$ in methanol/water $(1: 3, \mathrm{v}-\mathrm{v})$ at pH 4.5 and $\left[\mathrm{Fe}_{2}(\mathrm{CO})_{6}(\mu\right.$-adt $\left.) \mathrm{CH}_{2} \mathrm{C}_{6} \mathrm{H}_{5}\right] \mathrm{catalyst}$ $\left(3.00 \times 10^{-7} \mathrm{~mol}\right)$ with continuous sonication of the chitosan solution $\left(1.0 \mathrm{gl} \mathrm{I}^{-1}\right)$ in methanol/water $(1: 3, \mathrm{v}-\mathrm{v})$ at $\mathrm{pH} 4.5$. (b) The absorption spectra of chitosan $\left(1.0 \mathrm{gl}^{-1}\right)$ with progressive addition of $\left[\mathrm{Fe}_{2}(\mathrm{CO})_{6}(\mu\right.$-adt $\left.) \mathrm{CH}_{2} \mathrm{C}_{6} \mathrm{H}_{5}\right]\left(1.00 \times 10^{-3} \mathrm{moll}^{-1}\right.$ in $\left.\mathrm{CH}_{2} \mathrm{Cl}_{2}\right)$ in methanol/water $(1: 3$, $\mathrm{v}$ - $\mathrm{v})$ at $\mathrm{pH} 4.5$; inset: the absorbance at $336 \mathrm{~nm}$ as a function of amounts of $\left[\mathrm{Fe}_{2}(\mathrm{CO})_{6}\left(\mu\right.\right.$-adt) $\left.\mathrm{CH}_{2} \mathrm{C}_{6} \mathrm{H}_{5}\right]$ catalyst. (c) The schematic representation of dialysis experiment: the $10 \mathrm{ml}$ solution inside the dialyser containing $\left[\mathrm{Fe}_{2}(\mathrm{CO})_{6}(\mu\right.$-adt $\left.) \mathrm{CH}_{2} \mathrm{C}_{6} \mathrm{H}_{5}\right]$ catalyst $\left(1.00 \times 10^{-4}\right.$ moll $\left.\mathrm{I}^{-1}\right)$ in the absence $(A)$ and presence $(B)$ of chitosan $\left(1.0 \mathrm{gl}^{-1}\right)$ in methanol/water $(1: 3, \mathrm{v}-\mathrm{v})$ at $\mathrm{pH} 4.5$; the solution outside the dialyser containing $90 \mathrm{ml}$ of methanol/water (1:3, $\left.\mathrm{v}-\mathrm{v}\right)$ at $\mathrm{pH} 4.5$. (d) The time course of the concentration changes of $\left[\mathrm{Fe}_{2}(\mathrm{CO})_{6}(\mu\right.$-adt $\left.) \mathrm{CH}_{2} \mathrm{C}_{6} \mathrm{H}_{5}\right]$ catalyst outside the solution of dialysis bag $\mathrm{A}$ and dialysis bag $\mathrm{B}$, respectively, which was read from UV-vis absorption spectra. (e) Cyclic voltammograms of $\left[\mathrm{Fe}_{2}(\mathrm{CO})_{6}\left(\mu\right.\right.$-adt) $\left.\mathrm{CH}_{2} \mathrm{C}_{6} \mathrm{H}_{5}\right]$ catalyst $\left(2.0 \times 10^{-4}\right.$ mol I-1) in the absence and presence of $\mathrm{HOAc}$ in methanol/water $\left(1: 1, \mathrm{v}\right.$-v). (f) Cyclic voltammograms of $\left[\mathrm{Fe}_{2}(\mathrm{CO})_{6}(\mu\right.$-adt $\left.) \mathrm{CH}_{2} \mathrm{C}_{6} \mathrm{H}_{5}\right] \mathrm{catalyst}\left(2.0 \times 10^{-4}\right.$ mol I-1) in the absence and presence of HOAc in methanol/water (1:1, v-v) with chitosan $\left(1.0 \mathrm{gl}^{-1}\right)$.

$\left[\mathrm{Fe}_{2}(\mathrm{CO})_{6}(\mu\right.$-adt $\left.) \mathrm{CH}_{2} \mathrm{C}_{6} \mathrm{H}_{5}\right]$ catalyst determined as $-1.10 \mathrm{~V}$ in methanol/water $(1: 1, \mathrm{v}-\mathrm{v})$ at $\mathrm{pH} 4.5$ (Table 1), the excited-state energy $\left(E_{00}\right)$ of MPA-CdTe QDs being $2.23 \mathrm{eV}$ in the presence of chitosan and $2.16 \mathrm{eV}$ in the absence of chitosan at $\mathrm{pH} 4.5$ (Table 1), respectively, the free-energy change $\left(\Delta G^{0}\right)$ of the electron transfer reaction was thus calculated to be $-1.04 \mathrm{eV}$ in the presence of chitosan and $-0.97 \mathrm{eV}$ in the absence of chitosan at pH 4.5 (Table 1, Supplementary Fig. S14). This means that the electron transfer from the excited MPA-CdTe QDs to $\left[\mathrm{Fe}_{2}(\mathrm{CO})_{6}(\mu\right.$-adt $)$

$\mathrm{CH}_{2} \mathrm{C}_{6} \mathrm{H}_{5}$ ] catalyst in this designed system is more exothermic.

Flash photolysis study provides direct evidence on the photoinduced electron transfer process at room temperature.
On laser excitation of the MPA-CdTe QDs using $355 \mathrm{~nm}$ light, no characteristic absorption signal was observed from ultraviolet to visible region under the time scale of $2.0 \mu$ s (Supplementary Fig. S15). When $\left[\mathrm{Fe}_{2}(\mathrm{CO})_{6}\left(\mu\right.\right.$-adt) $\left.\mathrm{CH}_{2} \mathrm{C}_{6} \mathrm{H}_{5}\right]$ catalyst was added into the MPA-CdTe QDs solution containing $1.0 \mathrm{gl}^{-1}$ of chitosan, a new set of absorption bands emerged immediately (Fig. 6c). The generated new absorption is similar to that of $\left[\mathrm{Fe}_{2}(\mathrm{CO})_{6}\left(\mu\right.\right.$-adt) $\left.\mathrm{CH}_{2} \mathrm{C}_{6} \mathrm{H}_{5}\right]$ catalyst under reduction potential at $-1.16 \mathrm{~V}$ versus $\mathrm{NHE}$ in methanol/water $(1: 1, \mathrm{v}-\mathrm{v})$ at $\mathrm{pH} 4.5$ (Supplementary Fig. S15), in line with the $\mathrm{Fe}^{\mathrm{I}} \mathrm{Fe}^{0}$ species reported by Pickett and co-workers ${ }^{29}$ using the same approach. Therefore, the absorption $\sim 410 \mathrm{~nm}$ is attributed to the $\mathrm{Fe}^{\mathrm{I}} \mathrm{Fe}^{0}$ species generated by electron transfer from the excited MPA-CdTe 
a
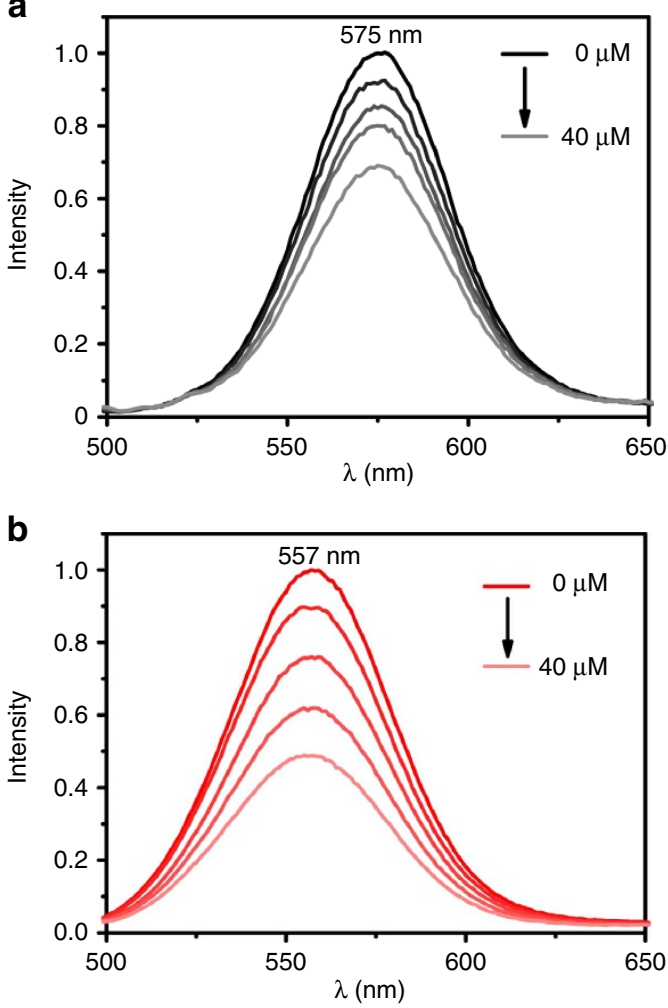

C

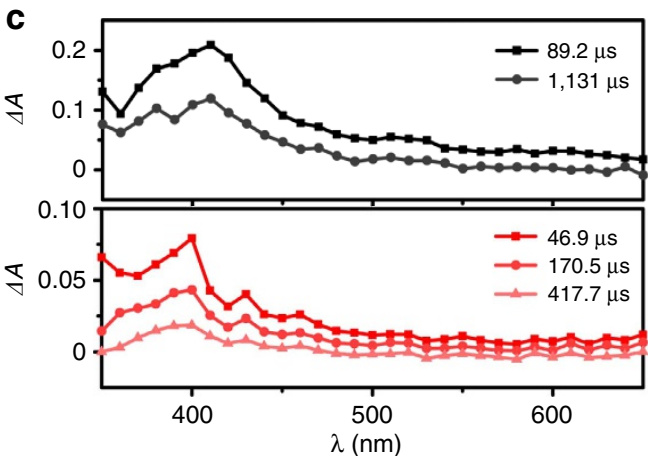

Figure 6 | Interaction of MPA-CdTe QDs and $\left[\mathrm{Fe}_{2}(\mathrm{CO})_{6}\left(\mu\right.\right.$-adt) $\left.\mathrm{CH}_{2} \mathrm{C}_{6} \mathrm{H}_{5}\right]$ with chitosan. (a) Photoluminescence quenching of MPA-CdTe QDs $\left(0.86 \times 10^{-6} \mathrm{moll}^{-1}\right)$ with progressive addition of $\left[\mathrm{Fe}_{2}(\mathrm{CO})_{6}(\mu-\right.$ adt) $\mathrm{CH}_{2} \mathrm{C}_{6} \mathrm{H}_{5}$ ] catalyst in the absence of chitosan. (b) Photoluminescence quenching of MPA-CdTe QDs $\left(0.86 \times 10^{-6} \mathrm{moll}^{-1}\right)$ with progressive addition of $\left[\mathrm{Fe}_{2}(\mathrm{CO})_{6}(\mu\right.$-adt $\left.) \mathrm{CH}_{2} \mathrm{C}_{6} \mathrm{H}_{5}\right]$ catalyst in the presence of chitosan. (c) Transient absorption spectra of MPA-CdTe QDs $\left(0.86 \times 10^{-6} \mathrm{moll}^{-1}\right)$ and $\left[\mathrm{Fe}_{2}(\mathrm{CO})_{6}(\mu\right.$-adt $\left.) \mathrm{CH}_{2} \mathrm{C}_{6} \mathrm{H}_{5}\right]$ catalyst $\left(5.00 \times 10^{-5} \mathrm{moll}^{-1}\right)$ in the absence (top) and presence (bottom) of chitosan in methanol/water $(1: 3 \mathrm{v}-\mathrm{v})$ at $\mathrm{pH} 4.5$.

QDs to $\left[\mathrm{Fe}_{2}(\mathrm{CO})_{6}(\mu\right.$-adt $\left.) \mathrm{CH}_{2} \mathrm{C}_{6} \mathrm{H}_{5}\right]$. As that of the MPA-CdTe QDs after delivering an electron to $\left[\mathrm{Fe}_{2}(\mathrm{CO})_{6}(\mu\right.$-adt $\left.) \mathrm{CH}_{2} \mathrm{C}_{6} \mathrm{H}_{5}\right]$ catalyst might show absorptions in this region though no signal was detected on laser excitation of MPA-CdTe QDs itself in methanol/water $(1: 3, \mathrm{v}-\mathrm{v})$ at $\mathrm{pH} 4.5$, we proposed that the transient signals at $\sim 410 \mathrm{~nm}$ may result from the spectral overlap of both $\mathrm{Fe}^{\mathrm{I}} \mathrm{Fe}^{0}$ species and that of the CdTe QDs after electron transfer. The active $\mathrm{Fe}^{\mathrm{I}} \mathrm{Fe}^{0}$ species from $\left[\mathrm{Fe}_{2}(\mathrm{CO})_{6}\right.$ ( $\mu$-adt) $\mathrm{CH}_{2} \mathrm{C}_{6} \mathrm{H}_{5}$ ] catalyst can further react with protons to experience catalytic cycle for $\mathrm{H}_{2}$ evolution. The formed hole remaining in the MPA-CdTe species after electron transfer, on the other hand, is subsequently regenerated by electron transfer from the sacrificial electron donor. It is known that the redox potential of $\mathrm{H}_{2} \mathrm{~A}(-0.14 \mathrm{~V} \text { at } \mathrm{pH} 4.5)^{59}$ is sufficiently negative to reduce the holes photogenerated in MPA-CdTe species ${ }^{25,45}$, but it is too positive to directly reduce the $[\mathrm{FeFe}]-\mathrm{H}_{2}$ ase catalyst (Supplementary Fig. S14). Therefore, the holes left in CdTe QDs are consumed by the sacrificial electron donor $\mathrm{H}_{2} \mathrm{~A}$.

To examine the possibility of chitosan to function as another electron donor, we did the experiment for $\mathrm{H}_{2}$ evolution in the absence of $\mathrm{H}_{2} \mathrm{~A}$ at pH 4.5 (Supplementary Fig. S2). But no $\mathrm{H}_{2}$ could be detected in the system, indicative that the functionality of chitosan to serve as a sacrificial electron donor would be negligible. In this case, one may speculate that when the MPACdTe QDs is excited by visible light, the electron transfer from the conduction band of MPA-CdTe QDs to $\left[\mathrm{Fe}_{2}(\mathrm{CO})_{6}(\mu\right.$-adt $)$ $\mathrm{CH}_{2} \mathrm{C}_{6} \mathrm{H}_{5}$ ] catalyst takes place giving rise to the reduced $\left[\mathrm{Fe}_{2}(\mathrm{CO})_{6}\left(\mu\right.\right.$-adt) $\left.\mathrm{CH}_{2} \mathrm{C}_{6} \mathrm{H}_{5}\right]$. At the same time, the holes remaining in the valence band of MPA-CdTe QDs after electron transfer are regenerated by electron transfer from the sacrificial ascorbic acid $\mathrm{H}_{2} \mathrm{~A}$ to complete the photocatalytic cycle (Supplementary Fig. S14).

\section{Discussion}

As compared with those reported in the literature ${ }^{34-51}$, the durability and activity of the present system are greatly increased; possibly as a result of the stabilization of the components by chitosan confinement leading to consecutive multi-step electron transfer in equilibrium. The importance of the stabilization was also analysed by exchanging chitosan for relatively small and loose aggregates, anionic SDS $\left(0.166 \mathrm{moll}^{-1}\right)$ and cationic $\mathrm{CTAB}$ $\left(0.055 \mathrm{moll}^{-1}\right.$, cetyl trimethyl ammonium bromide) micelles ${ }^{37}$. For systematic comparison, the photocatalytic $\mathrm{H}_{2}$ evolution experiment was carried out from the same reaction system, containing MPA-CdTe QDs, $\left[\mathrm{Fe}_{2}(\mathrm{CO})_{6}(\mu\right.$-adt $\left.) \mathrm{CH}_{2} \mathrm{C}_{6} \mathrm{H}_{5}\right]$ catalyst and $\mathrm{H}_{2} \mathrm{~A}$, in SDS and CTAB micelles, respectively. The TON is only $37.6 \pm 3.2$ and $36.0 \pm 4.4$ for the SDS and CTAB system, respectively, even after irradiation for $10 \mathrm{~h}$ (Supplementary Fig. S16). Notably, these solutions were quickly changed from orange to brownish red with the formation of brown precipitates on irradiation, whereas the chitosan-involved system was clear even after $40 \mathrm{~h}$ irradiation. The results demonstrate that the chitosan-confined $\mathrm{H}_{2}$-evolving system has more advantage over the micellar systems. The significant content of hydroxyl group and protonated amines of polycationic chitosan has shown affinity towards the negative MPA-CdTe QDs, $\left[\mathrm{Fe}_{2}(\mathrm{CO})_{6}(\mu\right.$-adt $)$ $\mathrm{CH}_{2} \mathrm{C}_{6} \mathrm{H}_{5}$ ] catalyst and $\mathrm{H}_{2} \mathrm{~A}$, which improves the electron transfer processes from the MPA-CdTe QDs to $\left[\mathrm{Fe}_{2}(\mathrm{CO})_{6}(\mu\right.$-adt $)$ $\mathrm{CH}_{2} \mathrm{C}_{6} \mathrm{H}_{5}$ ], as well as $\mathrm{H}_{2} \mathrm{~A}$ to the holes of MPA-CdTe QDs after electron transfer (see above). Because two electrons are required to produce each molecule of $\mathrm{H}_{2}$, the stabilization of the MPACdTe QDs, $\left[\mathrm{Fe}_{2}(\mathrm{CO})_{6}(\mu\right.$-adt $\left.) \mathrm{CH}_{2} \mathrm{C}_{6} \mathrm{H}_{5}\right]$ catalyst and catalytic intermediate and the consecutive multi-step electron transfer in equilibrium are believed to be responsible for the regeneration of the MPA-CdTe species and $\left[\mathrm{Fe}_{2}(\mathrm{CO})_{6}(\mu\right.$-adt $\left.) \mathrm{CH}_{2} \mathrm{C}_{6} \mathrm{H}_{5}\right]$ catalyst to improve the efficiency of $\mathrm{H}_{2}$ evolution in the chitosan-confined system.

Unlike most state-of-the-art approaches, the system does not rely on further structure modification of butterfly $\left[\mathrm{Fe}_{2} \mathrm{~S}_{2}\right]$ subunit but on the addition of natural polysaccharide chitosan. The catalytic performance has been improved from $12.7 \pm 1.3$ to $(5.28 \pm 0.17) \times 10^{4}$ turnover numbers under the same condition, which increases $4.16 \times 10^{3}$ folds as compared with the same system without chitosan. These results imply that the environmental protein surrounding catalytic centre might cause the significant activity difference between the diiron subsite of natural 
$[\mathrm{FeFe}]-\mathrm{H}_{2}$ ase and its synthetic mimics. The crucial role of chitosan suggests that to create active $\mathrm{H}_{2}$ evolution systems based on artificial [ $[\mathrm{FeFe}]-\mathrm{H}_{2}$ ases, one would need to mimic not only the structure of active centre but also the biological environment surrounding $\left[\mathrm{Fe}_{2} \mathrm{~S}_{2}\right]$ subunit. The present artificial system using chitosan-confined environment is reminiscent of the $\left[\mathrm{Fe}_{2} \mathrm{~S}_{2}\right]$ subcluster of natural $[\mathrm{FeFe}]-\mathrm{H}_{2}$ ase buried in heterogeneous protein matrix, and demonstrates that artificial $[\mathrm{FeFe}]-\mathrm{H}_{2}$ ases are promising alternatives for use in a future sustainable $\mathrm{H}_{2}$ economy.

\section{Methods}

Chemicals and synthesis. All reagents were weighed and handled in air, and backfilled under an inert atmosphere of argon at room temperature. Chitosan (low molecular weight, $20-300 \mathrm{cP}, 1 \mathrm{wt}$. $\%$ in $1 \%$ acetic acid $\left(25^{\circ} \mathrm{C}\right.$, Brookfield (lit.)), L-ascorbic acid $\left(\mathrm{H}_{2} \mathrm{~A}, 99 \%\right)$, MPA $(99 \%)$ and $\mathrm{CdCl}_{2} \cdot 2.5 \mathrm{H}_{2} \mathrm{O}(99 \%)$ were purchased from Sigma-Aldrich. Benzylamine (97\%) and paraformaldehyde (97\%) were purchased from Alfa-Aesar. All commercial chemicals are used without further purification unless otherwise noted. The ultrapure water with $18.2 \mathrm{M} \Omega \mathrm{cm}$ (Mettler Toledo, FE20) was used throughout the experiment.

The $\left[\mathrm{Fe}_{2}(\mathrm{CO})_{6}(\mu\right.$-adt $\left.) \mathrm{CH}_{2} \mathrm{C}_{6} \mathrm{H}_{5}\right]$ catalyst was synthesized by the reaction of benzylamine, aldacide, thionylchloride and the lithium salt of diiron hexacarbonyldisulphide as that repoted in the previous work ${ }^{27,37}$. The aqueous colloidal MPA-CdTe QDs solution was prepared using the reaction between $\mathrm{Cd}^{2+}$ and NaHTe solution according to the literature ${ }^{45} \cdot \mathrm{Cd}^{2}+$ precursor solutions were prepared by mixing the solutions of $\mathrm{CdCl}_{2} \cdot 2.5 \mathrm{H}_{2} \mathrm{O}$ and stabilizer (MPA) followed by $\mathrm{pH}$ adjustment to 10 with $1 \mathrm{moll}^{-1} \mathrm{NaOH}$ and degassed by bubbling nitrogen for $30 \mathrm{~min}$. Then a fresh NaHTe was added under anaerobic condition in a typical molar ratio of Cd:MPA:Te as 1:1.2:0.2. The resulting solution was then heated to 99- $100^{\circ} \mathrm{C}$ after bubbling nitrogen for another $30 \mathrm{~min}$ and refluxed in different reaction time to control the size of MPA-CdTe QDs. Aliquots of the reaction solution were taken out at regular intervals for UV-vis absorption and photoluminescence characterization.

Photocatalytic $\mathbf{H}_{\mathbf{2}}$ evolution. A typical procedure for $\mathrm{H}_{2}$ production is as follows. Chitosan $(10 \mathrm{mg})$ and $\mathrm{H}_{2} \mathrm{~A}\left(2.00 \times 10^{-3} \mathrm{~mol}\right)$ were dissolved in $3.50 \mathrm{ml}$ water and diluted with the $2.49 \mathrm{ml}$ methanol with vigorous stirring. The excess acid was then neutralized by adding $\mathrm{NaOH}\left(5.0 \mathrm{moll}^{-1}\right)$ solution and adjusted the solution to weakly acidic ( $\mathrm{pH} 4 \sim 5$ ). Then, $4.00 \mathrm{ml}$ of aqueous MPA-CdTe QDs solution $\left(1.71 \times 10^{-6} \mathrm{moll}^{-1}\right), 10.0 \mu \mathrm{l}$ of methanol solution containing $\left[\mathrm{Fe}_{2}(\mathrm{CO})_{6}(\mu-\right.$ adt) $\mathrm{CH}_{2} \mathrm{C}_{6} \mathrm{H}_{5}$ ] catalyst $\left(1.00 \times 10^{-3} \mathrm{moll}^{-1}\right)$ were added to the above solution (total volume became $10 \mathrm{ml}$ ) with stirring. The $\mathrm{pH}$ value of the mixed solution was further adjusted to 4.5 by aqueous $1.0 \mathrm{moll}^{-1} \mathrm{HCl}$ and determined by a pH meter. The sample was degassed by bubbling nitrogen for $30 \mathrm{~min}$. Then $1,000 \mu \mathrm{l}$ of $\mathrm{CH}_{4}$ was injected as the internal standard for quantitative GC analysis. The sample was irradiated by light-emitting diodes $(\lambda=410 \mathrm{~nm})$. The generated photoproduct of $\mathrm{H}_{2}$ was characterized by GC analysis (Tianmei 7890-II) using nitrogen as the carrier gas with a molecular sieve column $(5 \AA)$ and a thermal conductivity detector. Then $400 \mu \mathrm{l}$ of mixed gas was extracted from the sample tube and injected into the GC immediately. The response factor for $\mathrm{H}_{2} / \mathrm{CH}_{4}$ was about 5.10 under the experimental condition, which was established by calibration with known amounts of $\mathrm{H}_{2}$ and $\mathrm{CH}_{4}$ and determined before and after a series of measurements. The desired concentration of reaction system was achieved by dissolving different amount of chitosan, $\mathrm{H}_{2} \mathrm{~A}$, the MPA-CdTe QDs and $\left[\mathrm{Fe}_{2}(\mathrm{CO})_{6}(\mu\right.$-adt $\left.) \mathrm{CH}_{2} \mathrm{C}_{6} \mathrm{H}_{5}\right]$ catalyst into $10 \mathrm{ml}$ of the mixed aqueous solution.

\section{Absorption and photoluminescence measurements. UV-vis spectra were measured on a Shimadzu UV-1601PC spectrophotometer in a quartz cell with an optical path length of $1 \mathrm{~cm}$. The interaction of $\left[\mathrm{Fe}_{2}(\mathrm{CO})_{6}(\mu\right.$-adt $\left.) \mathrm{CH}_{2} \mathrm{C}_{6} \mathrm{H}_{5}\right]$ catalyst $\left(0.30 \times 10^{-6} \mathrm{~mol}\right.$, solid $)$ and chitosan $\left(1.0 \mathrm{gl}^{-1}\right.$, in methanol/water $\left.(1: 3, \mathrm{v}-\mathrm{v})\right)$ was sonicated for $15 \mathrm{~min}$ before measurement. Photoluminescence was recorded on a Hitachi F-4500 spectrofluorimeter at room temperature. Photoluminescence life- time was measured on the Edinburgh FLSP920 with excitation at $405 \mathrm{~nm}$. The photoluminescence quenching experiment was performed by progressive addition of $\left[\mathrm{Fe}_{2}(\mathrm{CO})_{6}(\mu\right.$-adt $\left.) \mathrm{CH}_{2} \mathrm{C}_{6} \mathrm{H}_{5}\right]$ catalyst $\left(1.0 \times 10^{-3} \mathrm{moll}^{-1}\right.$, in methanol $)$ into the solution at $\mathrm{pH} 4.5$. The volume of $\left[\mathrm{Fe}_{2}(\mathrm{CO})_{6}(\mu\right.$-adt $\left.) \mathrm{CH}_{2} \mathrm{C}_{6} \mathrm{H}_{5}\right]$ catalyst added to the system is so small that the volume change is ignored in the determination of the concentration.}

Dialysis experiments. The dialyser bags (purchased from Biotopped, molecular weight cutoff 3,500 ) were pretreated with hot water and kept in deionized water before use. Mixed solution $(10 \mathrm{ml})$ containing $\left[\mathrm{Fe}_{2}(\mathrm{CO})_{6}(\mu\right.$-adt $\left.) \mathrm{CH}_{2} \mathrm{C}_{6} \mathrm{H}_{5}\right]$ and chitosan was loaded into the dialyser bag. Then, the seal-off dialyser bag was soaked in $90 \mathrm{ml}$ solution of methanol/water $(1: 3, \mathrm{v}-\mathrm{v})$ in the dark. UV-vis absorption spectrometer was employed to examine the concentration of $\left[\mathrm{Fe}_{2}(\mathrm{CO})_{6}(\mu\right.$-adt $\left.) \mathrm{CH}_{2} \mathrm{C}_{6} \mathrm{H}_{5}\right]$ outside dialysis bag.
Electrochemical and spectroelectrochemical measurements. A three-electrode system was used for the measurement and bulk electrolysis, with a 3-mm glass carbon working electrode, a platinum wire counter electrode and a non-aqueous $\mathrm{Ag} / \mathrm{AgNO}_{3}$ reference electrode for organic solution or a saturated calomel electrode (SCE) reference electrode for aqueous solution. The working electrode was polished with a $0.05 \mu \mathrm{m}$ alumina paste and sonicated for $15 \mathrm{~min}$ before use. The electrolyte solution $\left(0.1 \mathrm{moll}^{-1}\right.$ of $n-\mathrm{Bu}_{4} \mathrm{NPF}_{6}$ in acetonitrile for organic solution, $0.1 \mathrm{moll}^{-1}$ of $\mathrm{Na}_{2} \mathrm{SO}_{4}$ for methanol/water $(1: 1 \mathrm{v}$-v) solution) was purged with argon for $30 \mathrm{~min}$ before measurement. Spectroelectrochemical experiment was performed in a quartz cell with an optical path length of $1 \mathrm{~cm}$. Indium tin oxide glass was used as a working electrode and a platinum wire electrode and a SCE reference electrode were served as the counter and reference electrodes, respectively. The electrolyte solution was purged with argon for $30 \mathrm{~min}$ before the absorption spectra were recorded on a Shimadzu UV-1601PC spectrometer. Spectroelectrochemical absorption spectrum was recorded along with time of electrochemical reduction of $\left[\mathrm{Fe}_{2}(\mathrm{CO})_{6}(\mu\right.$-adt $\left.) \mathrm{CH}_{2} \mathrm{C}_{6} \mathrm{H}_{5}\right]$ catalyst at $-1.4 \mathrm{~V}$ relative to $\mathrm{SCE}(-1.16 \mathrm{~V}$ versus $\mathrm{NHE})$ in methanol/water $(1: 1, \mathrm{v}-\mathrm{v})$, the baseline of which refers to the absorption of $\left[\mathrm{Fe}_{2}(\mathrm{CO})_{6}(\mu\right.$-adt $\left.) \mathrm{CH}_{2} \mathrm{C}_{6} \mathrm{H}_{5}\right]$ catalyst before reduction under the voltage.

Flash photolysis. The transient absorption spectroscopy was recorded on Edinburgh LP 920 at room temperature. A mixture of methanol/water (1:3 v-v) solution was degassed with nitrogen for $30 \mathrm{~min}$ before measurement. Excitation was provided using Nd:YAG laser (third harmonic, $10 \mathrm{~ns}$ ) at $355 \mathrm{~nm}$ and the detector was a xenon lamp on the Edinburgh LP 920 apparatus.

\section{References}

1. Frey, M. Hydrogenases: hydrogen-activating enzymes. Chembiochem. 3, 153-160 (2002).

2. Knörzer, P. et al. Importance of the protein framework for catalytic activity of [FeFe]-hydrogenases. J. Biol. Chem. 287, 1489-1499 (2012).

3. Nicolet, Y. \& Fontecilla-Camps, J. C. Structure-function relationships in [FeFe]-hydrogenase active site maturation. J. Biol. Chem. 287, 13532-13540 (2012).

4. Fontecilla-Camps, J. C., Volbeda, A., Cavazza, C. \& Nicolet, Y. Structure/ function relationships of $[\mathrm{NiFe}]-$ and $[\mathrm{FeFe}]$-hydrogenases. Chem. Rev. 107, 4273-4303 (2007).

5. Adams, M. W. W. \& Stiefel, E. I. Biological hydrogen production: not so elementary. Science 282, 1842-1843 (1998).

6. Stripp, S., Sanganas, O., Happe, T. \& Haumann, M. The structure of the active site $\mathrm{H}$-cluster of [FeFe] hydrogenase from the green algae Chlamydomonas reinhardtii studied by X-ray absorption spectroscopy. Biochem. 48, 5042-5049 (2009).

7. Woolerton, T. W., Sheard, S., Chaudhary, Y. S. \& Armstrong, F. A. Enzymes and bio-inspired electrocatalysts in solar fuel devices. Energy Environ. Sci. 5, 7470-7490 (2012).

8. Lubitz, W., Reijerse, E. J. \& Messinger, J. Solar water-splitting into $\mathrm{H}_{2}$ and $\mathrm{O}_{2}$ : design principles of photosystem II and hydrogenases. Energy Environ. Sci. 1, 15-31 (2008).

9. Hambourger, M. et al. Biology and technology for photochemical fuel production. Chem. Soc. Rev. 38, 25-35 (2009).

10. Tard, C. \& Pickett, C. J. Structural and functional analogues of the active sites of the [Fe]-, [NiFe]-, and [FeFe]-hydrogenases. Chem. Rev. 109, 2245-2274 (2009).

11. Gloaguen, F. \& Rauchfuss, T. B. Small molecule mimics of hydrogenases: hydrides and redox. Chem. Soc. Rev. 38, 100-108 (2009).

12. Capon, J.-F., Gloaguen, F., Pétillon, F. Y., Schollhammer, P. \& Talarmin, J. Electron and proton transfers at diiron dithiolate sites relevant to the catalysis of proton reduction by the $[\mathrm{FeFe}]$-hydrogenases. Coord. Chem. Rev. 253, 1476-1494 (2009).

13. Lomoth, R. \& Ott, S. Introducing a dark reaction to photochemistry: photocatalytic hydrogen from [FeFe] hydrogenase active site model complexes. Dalton. Trans. 45, $9952-9959$ (2009).

14. Magnuson, A. et al. Biomimetic and microbial approaches to solar fuel generation. Acc. Chem. Res. 42, 1899-1909 (2009).

15. Wang, M. \& Sun, L. Hydrogen production by noble-metal-free molecular catalysts and related nanomaterials. ChemSusChem 3, 551-554 (2010).

16. Concepcion, J. J., House, R. J., Papanikolas, J. M. \& Meyer, T. J. Chemical approaches to artificial photosynthesis. Proc. Natl Acad. Sci. USA 109, 15560-15564 (2012).

17. Han, Z.-J., Qiu, F., Eisenberg, R., Holland, P. L. \& Krauss, T. D. Robust photogeneration of $\mathrm{H}_{2}$ in water using semiconductor nanocrystals and a nickel catalyst. Science 338, 1321-1324 (2012).

18. Nocera, D. G. The artificial leaf. Acc. Chem. Res. 45, 767-776 (2012).

19. Balzani, V., Credi, A. \& Venturi, M. Photochemical conversion of solar energy. ChemSusChem 1, 26-58 (2008).

20. Andreiadis, E. S., Chavarot-Kerlidou, M., Fontecave, M. \& Artero, V. Artificial photosynthesis: from molecular catalysts for light-driven water splitting to photoelectrochemical cells. Photochem. Photobiol. 87, 946-964 (2011). 
21. Frischmann, P. D., Mahata, K. \& Wurthner, F. Powering the future of molecular artificial photosynthesis with light-harvesting metallosupramolecular dye assemblies. Chem. Soc. Rev. 42, 1847-1870 (2013).

22. Wang, F. et al. Artificial photosynthetic systems based on [FeFe]-hydrogenase mimics: the road to high efficiency for light-driven hydrogen evolution. ACS Catal. 2, 407-416 (2012).

23. Greene, B. L., Joseph, C. A., Maroney, M. J. \& Dyer, R. B. Direct evidence of active-site reduction and photodriven catalysis in sensitized hydrogenase assemblies. J. Am. Chem. Soc. 134, 11108-11111 (2012).

24. Reisner, E., Powell, D. J., Cavazza, C., Fontecilla-Camps, J. C. \& Armstrong, F. A. Visible light-driven $\mathrm{H}_{2}$ production by hydrogenases attached to dye-sensitized $\mathrm{TiO}_{2}$ nanoparticles. J. Am. Chem. Soc. 131, 18457-18466 (2009).

25. Brown, K. A., Dayal, S., Ai, X., Rumbles, G. \& King, P. W. Controlled assembly of hydrogenase-CdTe nanocrystal hybrids for solar hydrogen production. J. Am. Chem. Soc. 132, 9672-9680 (2010).

26. Gloaguen, F., Lawrence, J. D. \& Rauchfuss, T. B. Biomimetic hydrogen evolution catalyzed by an iron carbonyl thiolate. J. Am. Chem. Soc. 123, 9476-9477 (2001).

27. Barton, B. E., Olsen, M. T. \& Rauchfuss, T. B. Aza- and oxadi-thiolates are probable proton relays in functional models for the [FeFe]-hydrogenases. J. Am. Chem. Soc. 130, 16834-16835 (2008).

28. Mejia-Rodriguez, R., Chong, D., Reibenspies, J. H., Soriaga, M. P. \& Darensbourg, M. Y. The hydrophilic phosphatriazaadamantane ligand in the development of $\mathrm{H}_{2}$ production electrocatalysts: Iron hydrogenase model complexes. J. Am. Chem. Soc. 126, 12004-12014 (2004).

29. Borg, S. J. et al. Electron-transfer at a dithiolate-bridged di-Iron assembly; electrocatalytic hydrogen evolution. J. Am. Chem. Soc. 126, 16988-16999 (2004).

30. Quentel, F., Passard, G. \& Gloaguen, F. Electrochemical hydrogen production in aqueous micellar solution by a diiron benzenedithiolate complex relevant to [FeFe] hydrogenases. Energy Environ. Sci. 5, 7757-7761 (2012).

31. Camara, J. M. \& Rauchfuss, T. B. Combining acid-base, redox and substrate binding functionalities to give a complete model for the [FeFe]-hydrogenase. Nat. Chem. 4, 26-30 (2012).

32. Jones, A. K., Lichtenstein, B. R., Dutta, A., Gordon, G. \& Dutton, P. L. Synthetic hydrogenases:incorporation of an iron carbonyl thiolate into a designed peptide. J. Am. Chem. Soc. 129, 14844-14845 (2007).

33. Singleton, M. L., Reibenspies, J. H. \& Darensbourg, M. Y. A cyclodextrin host/ guest approach to a hydrogenase active site biomimetic cavity. J. Am. Chem. Soc. 132, 8870-8871 (2010).

34. Ott, S., Kritikos, M., Åkermark, B. \& Sun, L. Synthesis and structure of a biomimetic model of the iron hydrogenase active site covalently linked to a ruthenium photosensitizer. Angew. Chem. Int. Ed. 42, 3285-3288 (2003).

35. Na, Y. et al. Visible light-driven electron transfer and hydrogen generation catalyzed by bioinspired [2Fe2S] complexes. Inorg. Chem. 47, 2805-2810 (2008).

36. Streich, D. et al. High-turnover photochemical hydrogen production catalyzed by a model complex of the [FeFe]-hydrogenase active site. Chem. Eur. J. 16, 60-63 (2010).

37. Wang, H.-Y. et al. Photocatalytic hydrogen evolution from rhenium(I) complexes to [FeFe] hydrogenase mimics in aqueous SDS micellar systems: a biomimetic pathway. Langmuir. 26, 9766-9771 (2010).

38. Kluwer, A. M. et al. Self-assembled biomimetic [2Fe2S]-hydrogenase-based photocatalyst for molecular hydrogen evolution. Proc. Natl Acad. Sci. USA 106, 10460-10465 (2009).

39. Wang, W.-G. et al. Photocatalytic hydrogen evolution by [FeFe] hydrogenase mimics in homogeneous solution. Chem. Asian J. 5, 1796-1803 (2010).

40. Samuel, A. P. S., Co, D. T., Stern, C. L. \& Wasielewski, M. R. Ultrafast photodriven intramolecular electron transfer from a zinc porphyrin to a readily reduced diiron hydrogenase model complex. J. Am. Chem. Soc. 132, 8813-8815 (2010).

41. Wang, W.-G., Wang, F., Wang, H.-Y., Tung, C.-H. \& Wu, L.-Z. Electron transfer and hydrogen generation from a molecular dyad: platinum(II) alkynyl complex anchored to [FeFe] hydrogenase subsite mimic. Dalton Trans. 41, 2420-2426 (2012)

42. Poddutoori, P. et al. Photoinitiated multistep charge separation in ferrocenezinc porphyrin-diiron hydrogenase model complex triads. Energy Environ. Sci. 4, 2441-2450 (2011)

43. Wang, H.-Y. et al. A triad [FeFe] hydrogenase system for light-driven hydrogen evolution. Chem. Commun. 47, 8406-8408 (2011).

44. Nann, T. et al. Water splitting by visible light: a nanophotocathode for hydrogen production. Angew. Chem. Int. Ed. 49, 1574-1577 (2010).

45. Wang, F. et al. A highly efficient photocatalytic system for hydrogen production by a robust hydrogenase mimic in an aqueous solution. Angew. Chem. Int. Ed. 50, 3193-3197 (2011)
46. Wen, F. et al. A hybrid photocatalytic system comprising $\mathrm{ZnS}$ as light harvester and an $\left[\mathrm{Fe}_{2} \mathrm{~S}_{2}\right]$ hydrogenase mimic as hydrogen evolution catalyst. ChemSusChem 5, 849-853 (2012).

47. Cao, W.-N. et al. Photocatalytic hydrogen production from a simple watersoluble [FeFe]-hydrogenase model system. Chem. Commun. 48, 8081-8083 (2012).

48. Roy, A., Madden, C. \& Ghirlanda, G. Photo-induced hydrogen production in a helical peptide incorporating a $[\mathrm{FeFe}]$ hydrogenase active site mimic. Chem. Commun. 48, 9816-9818 (2012).

49. Sano, Y., Onoda, A. \& Hayashi, T. A hydrogenase model system based on the sequence of cytochrome c: photochemical hydrogen evolution in aqueous media. Chem. Commun. 47, 8229-8231 (2011).

50. Li, X., Wang, M., Zheng, D., Han, K., Dong, J. \& Sun, L. Photocatalytic $\mathrm{H}_{2}$ production in aqueous solution with host-guest inclusions formed by insertion of an FeFe-hydrogenase mimic and an organic dye into cyclodextrins. Energy Environ. Sci. 5, 8220-8224 (2012).

51. Wang, W.-G. \& Rauchfuss, T. B. Unsensitized photochemical hydrogen production catalyzed by diiron hydrides. J. Am. Chem. Soc. 134, 4525-4528 (2012).

52. Wu, S., Zeng, F., Zhu, H. \& Tong, Z. Energy and electron transfers in photosensitive chitosan. J. Am. Chem. Soc. 127, 2048-2049 (2005).

53. Yamada, Y., Hozumi, K. \& Nomizu, M. Construction and activity of a synthetic basement membrane with active laminin peptides and polysaccharides. Chem. Eur. J. 17, 10500-10508 (2011).

54. Kiang, T., Wen, J., Lim, H. W. \& Leong, K. W. The effect of the degree of chitosan deacetylation on the efficiency of gene transfection. Biomaterials 25, 5293-5301 (2004).

55. Aldana, J., Lavelle, N., Wang, Y. \& Peng, X. Size-dependent dissociation pH of thiolate ligands from cadmium chalcogenide nanocrystals. J. Am. Chem. Soc. 127, 2496-2504 (2005).

56. Zhang, Y., Mi, L., Wang, P.-N., Ma, J. \& Chen, J.-Y. pH-Dependent aggregation and photoluminescence behavior of thiol-capped CdTe quantum dots in aqueous solutions. J. Lumin. 128, 1948-1951 (2008).

57. Zhang, H., Zhou, Z. \& Yang, B. The influence of carboxyl groups on the photoluminescence of mercaptocarboxylic acid-stabilized CdTe nanoparticles. J. Phys. Chem. B 107, 8-13 (2003).

58. Rajh, T., Mićić, O. I. \& Nozik, A. J. Synthesis and characterization of surfacemodified colloidal CdTe qunatum dots. J. Phys. Chem. 97, 11999-12003 (1993).

59. Borsook, H. \& Keighley, G. Oxidation-reduction potential of ascorbic acid (vitamin C). Proc. Natl Acad. Sci. 19, 875-878 (1933).

60. Karstens, T. \& Kobs, K. Rhodamine B and rhodamine 101 as reference substances for fluorescence quantum yiels measurements. J. Phys. Chem. 84, 1871-1872 (1980).

\section{Acknowledgements}

We are grateful for financial support from the Ministry of Science and Technology of China (2013CB834505, 2013CB834804 and 2014CB239402), the National Natural Science Foundation of China (91027041, 21090343 and 51373193), the Solar Energy Initiative of the Knowledge Innovation Program of Chinese Academy of Sciences and the Bureau for Basic Research of the Chinese Academy of Sciences. We also acknowledge Ms. Yuejuan Ma for her help with the preparation of graphics.

\section{Author contributions}

L.-Z.W. designed the research and supervised the whole project. Q.L. initiated the exploration in experiments and contributed to data analysis. J.-X.J. and Q.L. prepared samples, and performed experiments with input from L.-Z.W. Z.-J.L., F.W., Q.-Y.M., K.F., B.C. and C.-H.T. helped with the discussion. X.-B.L. performed the high-resolution transmission electron microscopy measurements. B.L. helped in the electrochemical and spectroelectrochemical measurements. Z.-J.L. and C.-B.L. provided CdTe QDs and the $\left[\mathrm{Fe}_{2}(\mathrm{CO})_{6}(\mu\right.$-adt $\left.) \mathrm{CH}_{2} \mathrm{C}_{6} \mathrm{H}_{5}\right]$ catalyst. L.-Z.W. and Q.L. wrote the manuscript.

\section{Additional information}

Supplementary Information accompanies this paper at http://www.nature.com/ naturecommunications

Competing financial interests: The authors declare no competing financial interests.

Reprints and permission information is available online at http://npg.nature.com/ reprintsandpermissions/

How to cite this article: Jian, J.-X. et al. Chitosan confinement enhances hydrogen photogeneration from a mimic of the diiron subsite of [FeFe]-hydrogenase. Nat. Commun. 4:2695 doi: 10.1038/ncomms3695 (2013). 